\title{
Phenolic profile and antioxidant capacity of fruit Averrhoa carambola L.: a review
}

\author{
Ángel Félix VARGAS-MADRIZ1 ${ }^{1}$ (D), Aarón KURI-GARCÍA ${ }^{1}$, Haidel VARGAS-MADRIZ², \\ Jorge Luis CHÁVEZ-SERVÍN ${ }^{1 *}$ (D), Rosa Adriana AYALA-TIRADO ${ }^{3}$
}

\begin{abstract}
The fruit of Averrhoa carambola L. (A. carambola L.) belongs to the Oxalidaceae family, is probably native to Ceylon and Moluccas, and is commonly known in various places as "star-fruit" or "carambola." This fruit is used as traditional medicine for a variety of diseases. The phenolic compounds that the fruit contains are thought to be responsible for its many benefits. Currently there is extensive research on the content of phenolic compounds and the antioxidant capacity of the fruit of A. carambola L. Most authors report total phenolic content (TPC) and total flavonoid content (TFC); while antioxidant capacity has been analyzed using different techniques such as: 1,1-diphenyl-2-picrylhydrazyl assay (DPPH), ferric reducing antioxidant power assay (FRAP), and 2,2'-azino-bis (3-ethylbenzothiazoline-6-sulphonic acid) (ABTS). HPLC analysis has resulted in the identification of phenolic compounds in the fruit. However, each of the authors use different methodologies in the various stages of the analysis, from obtaining the sample to the form of analysis, and this may explain the differences in their results. This paper offers a review of existing research on the phenolic profile and antioxidant capacity of the A. carambola L. fruit, with special attention to the methodologies used.
\end{abstract}

Keywords: A. carambola L.; extraction; antioxidant capacity; phenolic compounds; HPLC.

Practical Application: The manuscript analyzes the methods of extraction and quantification of phenolic compounds from the fruit of Averrhoa carambola L. in different studies. This presents great interest in the area of biotechnology and food science.

\section{Introduction}

Since ancient times, human begins have relied on certain plants or herbs to treat the diseases that afflict them. This ancient knowledge has recently gained considerable interest in the pharmaceutical community (Dasgupta et al., 2013). One reason is that nearly $80 \%$ of the world's population in developing countries use traditional remedies (Lee et al., 2019), many of them based on the empirical knowledge, popular tradition, beliefs and culture of their society (Payal et al., 2012). Some foods, in addition to their nutritional characteristics, contain other bioactive compounds that can help maintain optimal health conditions, reducing the risk of non-communicable diseases such as diabetes, cancer, dyslipidemias and cardiovascular diseases. These foods are known as functional foods, and they must go through clinical trials that document the beneficial properties for the body. In some cases, these claims are regulated by certain government agencies such as the Food and Drug Administration (FDA), the Brazilian Agency for Sanitary Regulation (ANVISA), and others (Granato et al., 2020). In recent years, various groups of scientists have begun to analyze the composition of such plants and fruits, focusing on minority compounds - mainly phenolic compounds and their antioxidant capacity - which have been attributed with preventive and treatment effects against various chronic diseases (Lin et al., 2016). Phenolic compounds are secondary metabolites of plants that have protective functions against biotic and abiotic stress factors (Li et al., 2018). Their chemical structure is made up of one or more hydroxyl constituents attached to an aromatic ring, and according to their structure, they are divided into phenolic acids, simple phenols, flavonoids, coumarins, lignans and tannins (Valduga et al., 2019). Averrhoa carambola L. (A. carambola L.) is cultivated in India as an edible fruits and is also used for the treatment of various diseases (Thomas et al., 2008). There is currently a wide range of research available on phenolic compounds and antioxidant capacity of different plants. The results vary, however, and among the possible explanations are the many different methods for collecting and processing samples, the use of solvents and the form of expression of the results (Vargas-Madriz et al., 2020). The present work is an exhaustive review of the scientific literature on the phenolic profile and antioxidant capacity of the fruit of $A$. carambola $L$. with special attention to methods used.

\section{A. carambola $L$.}

The genus Averrhoa contains several species. among which is A. carambola L., known as star-fruit or carambola. It belongs to the Oxalidaceae family, a perennial tree native to tropical and subtropical places. It is thought to be native to Ceylon and Moluccas (Kurup \& Mini, 2017; Manda et al., 2012; Payal et al., 2012). It is cultivated in Southeast Asia and Malaysia, southern China, Taiwan and India, reported in the Philippines, Queensland, Australia and in some parts of the Pacific; the fruit is available from March to August (Dembitsky et al., 2011; Payal et al., 2012). 
This fruit is considered ideal for its nutritional value in macro and micro nutrients (Tables 1 and 2). The skin of the immature fruit is green, and as it matures, it becomes yellow. The fruit is usually oblong with a tart-sweet flavor. In cross section, the fruit resembles a star shape, hence its name. It is used traditionally for treating fever, eye problems, kidney and bladder issues, and indigestion. Various scientific studies have been carried out on this fruit to determine its hypoglycemic power, anti-inflammatory activity, antimicrobial activity, anti-ulcer effect and antioxidant activity (Manda et al., 2012; Muthu et al., 2016; Payal et al., 2012). A current study by Pothasak et al. (2020) reported that an extract of A. carambola L. has an anti-inflammatory effect on macrophage cells. However, there is a need for clinical studies to evaluate the possible effect of phenolic compounds that have been detected in the fruit of $A$. carambola $L$. on human health (Dionísio et al., 2020a, b).

\section{Sample treatment before extraction}

The treatment of the samples collected prior to extraction is essential when analyzing the compounds of interest from the plants. The different treatments reported by the authors who analyze the phenolic compounds and the antioxidant capacity of A. carambola $L$. are described in Table 3.

In most of the studies analyzed, the sample was collected in local markets, taking as inclusion criteria: the physical uniformity of the samples, the state of maturity, the color and size, and that no visible damage is observed in the fruits. Once obtained, they were washed (some authors report cutting the sample into small

Table 1. Proximate analysis of A. carambola L. fruit.

\begin{tabular}{ccc}
\hline & \multicolumn{2}{c}{ Reference } \\
\hline \multirow{2}{*}{ Component } & $\begin{array}{c}\text { Fresh A. carambola L. } \\
\text { fruit }\end{array}$ & $\begin{array}{c}\text { Freeze-dried A. } \\
\text { carambola L. fruit }\end{array}$ \\
\cline { 2 - 3 } & Payal et al. (2012) & Yan et al. (2013) \\
\hline Moisture (g) & 92.0 & 12.04 \\
Protein (g) & 0.7 & 3.87 \\
Fat (g) & 0.1 & 1.36 \\
Ash (g) & 0.4 & 7.88 \\
Carbohydrate (g) & 5.0 & 24.22 \\
Dietary fiber $(\mathrm{g})$ & 1.8 & 7.89 \\
\hline
\end{tabular}

Table 2. Main vitamins and minerals of the A. carambola L. fruit.

\begin{tabular}{ccc}
\hline \multirow{2}{*}{ Component } & A. carambola $L$. & A. carambola $L$. \\
\cline { 2 - 3 } & Manda et al. (2012) & Muthu et al. (2016) \\
\cline { 2 - 3 } & $\mathrm{mg} / 100 \mathrm{~g}$ & $\mathrm{mg} / 100 \mathrm{~g} \mathrm{DW}$ \\
\hline Vitamin A & $\mathrm{NR}$ & $\mathrm{NR}$ \\
Vitamin C & 1.32 & 25.8 \\
Vitamin B1 & $0.03-0.038$ & 0.1 \\
Vitamin B2 & $0.019-0.03$ & 0.1 \\
Calcium (Ca) & $4.4-6.0$ & $6.3-6.4$ \\
Magnesium $(\mathrm{Mg})$ & $\mathrm{NR}$ & $11.8-12.0$ \\
Phosphorous $(\mathrm{P})$ & $15.5-21.0$ & 17.8 \\
Potassium $(\mathrm{K})$ & 2.35 & $167.3-168.0$ \\
Sodium $(\mathrm{Na})$ & $\mathrm{NR}$ & 3.8 \\
\hline
\end{tabular}

DW: dry weight; NR: Not reported. The information is presented as described by the authors. pieces to facilitate homogenization in a blender or using a mortar). They then analyzed the fresh and dry samples (Shofian et al., 2011; Thomas et al., 2016). Other authors, after homogenizing the sample in a blender, centrifuged and filtered the sample (Shui \& Leong, 2004). Still others use liquid nitrogen to grind the samples (Lim \& Lee, 2013). Drying methods included shadedrying, sun-drying (Chauhan \& Kapfo, 2016; Verma et al., 2018) drying at room temperature (Batiston et al., 2013), by means of a hot air oven (Abdullah \& Noriham, 2014; Pothasak et al., 2020; Rahman et al., 2016; Ruvini et al., 2017) by means of a dehydrator, and freeze drying (lyophilization) (Guevara et al., 2019; Shofian et al., 2011; Shui \& Leong, 2006; Yan et al., 2013; Zainudin et al., 2014). Conventional methods are regularly used for their simplicity and low cost, but they involve high temperatures, some light exposure, and long times. The drying temperatures reported in the different investigations range from 40 to $65^{\circ} \mathrm{C}$, which is appropriate for avoiding degradation of compounds. Drying time is another important factor, and in these studies varies from a few hours to a few days. It has been observed that the appropriate combination of time and temperature deactivates of the polyphenol oxidase enzyme and eliminates microorganisms that degrade phenolic compounds. An improper drying process can cause oxidation reactions and degradation of components of interest (Teles et al., 2018). The freeze-drying (lyophilization) method is used in various studies for its effectiveness, obtaining greater porosity in the samples, decreased degradation of bioactive compounds, and a relatively short period of time to dry samples. The disadvantages of this method is its high cost and difficulty unskilled personnel have in handling the equipment (Gaidhani et al., 2016). After drying, some authors mention homogenizing the sample in a mill or in a blender. The particle size of the sample was not mentioned. Preferably, particle size should less than $0.5 \mathrm{~mm}$ in diameter in order to obtain an adequate contact surface with the solvent, favoring the extraction process (Pătrăuțanu et al., 2019). All the variables mentioned in the sample treatment, prior to the extraction process, are essential to avoid degrading phenolic compounds and decreasing antioxidant capacity (Makanjuola, 2017).

\section{Extractions of phenolic compounds from the fruit $A$. carambola $L$. with different solvents}

Table 3 summarizes the various methods used in the extraction process of A. carambola $L$. compounds, separated by type of solvent: water, ethanol, methanol, acetone, diethyl ether, in different proportions.

\subsection{Water extraction}

After sample treatment, Shui \& Leong (2004) mixed the solid residue of the sample in a $50 \%(\mathrm{v} / \mathrm{v})$ aqueous acetone solution, at $90{ }^{\circ} \mathrm{C}$ for $45 \mathrm{~min}$. The extract was then concentrated using a rotary evaporator and stored at $-18^{\circ} \mathrm{C}$. Annegowda et al. (2012) extracted the plant sample in an ultrasonicator $(42 \mathrm{kHz}, 135 \mathrm{~W}$; Branson ultrasonic corporation, USA) using a solid/solvent ratio of $1: 10(\mathrm{w} / \mathrm{v})$ at $25 \pm 1{ }^{\circ} \mathrm{C}$ and at different extraction times: $15,30,45$ and 60 minutes, under low light conditions. After the extraction time had elapsed, the residue was re-extracted 
Table 3. Studies that have reported the compositional analysis of A. carambola L. fruits.

\begin{tabular}{l} 
Sample treatment \\
\hline The sample was homogenized in a blender, centrifuged, \\
and vacuum filtered. \\
\\
All the sample had uniform color, maturation time and \\
size. The sample was washed with tap water followed by \\
distilled water, then homogenized in a blender.
\end{tabular}

Solvent/extraction process
Water extraction
solid residue was mixed with $50 \%(\mathrm{v} / \mathrm{v})$ water/
tone at $90{ }^{\circ} \mathrm{C}$ for $45 \mathrm{~min}$, then evaporated under
uced pressure and filled with water to a certain
ume, and stored at $-18{ }^{\circ} \mathrm{C}$.
$\mathrm{g}$ of sample was mixed in water at a ratio of $1: 10$
$\mathrm{v})$. An ultrasonicator was used in low light conditions
$(\mathrm{w} / \mathrm{v})$. An ultrasonicator was used in low light conditions in a rotary evaporator, and finally the concentrate was lyophilized.

The vegetable sample was obtained from tart-type and honey-type A. carambola $L$., classified in two maturity stages: 3 and 4 .

$20 \mathrm{~g}$ were placed in $600 \mathrm{~mL}$ of boiling water at a ratio of 1:30 (w/v), subsequently filtered (Whatman No.4) and the extract concentrated using a rotary evaporator at The sample was washed with running water and dried in $70^{\circ} \mathrm{C}$. The sample was stored at $4{ }^{\circ} \mathrm{C}$. an oven, then later ground.

The sample was washed and cut into small parts. $100 \mathrm{~g}$ were placed in $200 \mathrm{~mL}$ of water at a 1:2 (w/v) ratio. It was then immersed in a $40^{\circ} \mathrm{C}$ water bath and after $24 \mathrm{~h}$ the extract was filtered through filter paper and evaporated at $40{ }^{\circ} \mathrm{C}$. The concentrate was stored at $4{ }^{\circ} \mathrm{C}$.

The sample was chosen from fruit not too mature or $200 \mathrm{~g} \mathrm{DM}$ and 2,000 g FM were placed in 500 and 5,000 damaged; it was cut into uniform size. A part of the sample $\mathrm{mL}$ at a ratio of 2:5 (w/v) in water/acetone at $60 \%(\mathrm{v} / \mathrm{v})$. $(5 \mathrm{~kg})$ was stored in the shade and another dried in the sun The mixture was stirred for $3 \mathrm{~h}$ at room temperature, for 4 days, then it was milled in a blender. The other part of then the extracts filtered and evaporated. The aqueous the sample was used fresh. portion was dried in a hot air oven at $50^{\circ} \mathrm{C}$.

Extraction using ethanol and mix polar solvents

$25 \mathrm{~mL}$ of $50 \%(\mathrm{v} / \mathrm{v})$ ethanol was added to a sample using

The samples obtained were peeled and homogenized in a a $1: 10(\mathrm{w} / \mathrm{v})$ ratio. The sample was sonic and mixed in a blender. vortex for $60 \mathrm{~s}$. The extract was centrifuged at 2,000 $\mathrm{g}$ for Leong \& Shui (2002) $5 \mathrm{~min}$ at room temperature and finally filtered.

The sample was mixed in $100 \mathrm{~mL}$ of $50 \%(\mathrm{v} / \mathrm{v})$ ethanol

Whole samples weighing between 10 and $30 \mathrm{~g}$ (including with stirring for $10 \mathrm{~min}$ and was subsequently filtered. peel) were crushed for $1 \mathrm{~min}$ using a blender then whe supernatant was used for analysis, it was stored at homogenized in a mortar. $-20^{\circ} \mathrm{C}$.

NR

NR The sample was mixed with $60 \%(\mathrm{v} / \mathrm{v})$ ethanol. The extract was concentrated by means of a rotary evaporator.

$4 \mathrm{~g}$ in $8 \mathrm{~mL}$ of $50 \%(\mathrm{v} / \mathrm{v})$ ethanol at a ratio of $1: 2(\mathrm{w} / \mathrm{v})$, at room temperature for 30 min with occasional stirring, then the extract was centrifuged at 2,000 $\mathrm{xg}$ for $15 \mathrm{~min}$.

The samples were washed with running water and the ends of the fruit removed. It was then cut into uniform pieces $2 \mathrm{~g}$ in $50 \mathrm{~mL}$ of ethanol $70 \%(\mathrm{v} / \mathrm{v})$ at a ratio of 1:25 (w/v), and homogenized in a blender for $2 \mathrm{~min}$. Subsequently it stirring at $200 \mathrm{rpm}$ for $120 \mathrm{~min}$ at $50{ }^{\circ} \mathrm{C}$. The mixture was was stored at $-80^{\circ} \mathrm{C}$ and lyophilized for 3 days, then the centrifuged at $3,000 \mathrm{rpm}$ for $15 \mathrm{~min}$ at room temperature sample was ground through a fine mesh and stored at -20 and the supernatant was stored at $-20^{\circ} \mathrm{C}$.

${ }^{\circ} \mathrm{C}$.

The samples were selected for uniformity in size, color, $100 \mathrm{~g}$ in $200 \mathrm{~mL}$ of ethanol at a ratio of 1: $2(\mathrm{w} / \mathrm{v})$, it maturation stage and without any damage. They were was immersed in a water bath at $40{ }^{\circ} \mathrm{C}$ and after $24 \mathrm{~h}$ washed, their peel was removed manually and cut into the extract was filtered and evaporated at $40{ }^{\circ} \mathrm{C}$. The small parts. concentrate was stored at $4{ }^{\circ} \mathrm{C}$.

The sample was mixed in acidified ethanol ( $1 \% 1 \mathrm{~N}$ hydrochloric acid, $\mathrm{pH} 3.0)$ at a ratio of $1: 10(\mathrm{w} / \mathrm{v})$

Ripe samples were obtained and a juice prepared using a domestic juice processor. The resulting pomace was dried at $50^{\circ} \mathrm{C}$ for $12 \mathrm{~h}$, then ground and stored at $-20^{\circ} \mathrm{C}$.
年 concentrations of solvents $(43,50,65,80,86 \%)$. The extracts stirred for $3 \mathrm{~h}$. They were then spun at 3,000 rpm for $15 \mathrm{~min}$. Abdullah \& Noriham (2014) Khanam et al. (2015) Chauhan \& Kapfo (2016)

Shui \& Leong (2004)

Chauhan \& Kapfo (2016)
Lim et al. (2007)

Muñoz-Jáuregui et al. (2007)

Ali et al. (2010)

Yan et al. (2013)

Khanam et al. (2015)

Saikia et al. (2015)

DM: dry matter; FM: fresh matter; NR: not reported. Results presented as reported by the authors. 
Table 3. Continued...

\begin{tabular}{lll}
\hline \multicolumn{1}{c}{ Sample treatment } & Solvent/extraction process & Reference \\
\hline The collection was carried out twice. The samples obtained & & \\
were in the same stage of maturation and without any A hydroalcoholic extraction was performed (the \\
damage. The samples were cut into small pieces to be relationship is not reported).
\end{tabular}

lyophilized and ground, then stored at $-20^{\circ} \mathrm{C}$.

Extraction using methanol and mix polar solvents

$20 \mathrm{~g}$ of sample was placed in $80 \mathrm{~mL}$ of $100 \%(\mathrm{v} / \mathrm{v})$

methanol at a ratio of 1: $4(\mathrm{w} / \mathrm{v})$, mixed in a blender for

$1 \mathrm{~min}$ and subsequently filtered. The residue from the

Mahattanatawee et al. (2006)

The sample was cut and frozen with liquid nitrogen, it was stored at $-20^{\circ} \mathrm{C}$ prior to extraction. extract was re-extracted and filtered. Finally the extracts were concentrated in a rotary evaporator at $40^{\circ} \mathrm{C}$.

The samples were selected for uniformity in texture, size and color; They were washed with distilled water and the sample subsequently homogenized by means of a kitchen mixer for $3 \mathrm{~min}$. The vegetable sample was exposed to UV light at different times from 0 to $60 \mathrm{~min}$.

A part of the sample was cut for analysis while fresh, and the other part of the sample was lyophilized for 3 days.

The samples were selected for uniformity in texture, Then they were sonicated at different times $(15,30$, size, color, maturity and without apparent damage from $45,60 \mathrm{~min}$ ) at $25 \pm 1{ }^{\circ} \mathrm{C}$ and in low light. The residues microorganisms. They were washed with running water were dissolved in the same ratio until the extract was followed by distilled water 2 to 3 times.

The samples were collected in their mature stage, washed with running water, cut and liquefied for $2 \mathrm{~min}$.

The samples were obtained in the mature stage and stored at $5{ }^{\circ} \mathrm{C}$, and only those with no visible damage were analyzed.

The sample was washed at room temperature and cut into $2 \times 2 \mathrm{~cm}$ pieces, then stored in polypropylene boxes with transparent lids. Two treatments were performed: one group was stored in the dark and the other group under fluorescent light, both treatments were exposed to $5 \pm 1^{\circ} \mathrm{C}$ for 12 days.

The samples were collected during three consecutive The samples were mixed with methanol at a ratio of 1:10 weeks, washed with deionized water and dried at room (w/v), stirring for $4 \mathrm{~h}$ under low light. The extract was temperature, and then ground.

filtered and concentrated by a rotary evaporator.

Ripe and immature samples were collected and peeled manually, and the samples were ground using liquid nitrogen and stored at $-80^{\circ} \mathrm{C}$.

The samples were obtained in the mature stage, washed and cut into cubes, after which they were lyophilized and ground.

cut into small pieces.
A ratio of $1: 10(\mathrm{w} / \mathrm{v})$ was used, extraction was carried out with stirring at $1,100 \mathrm{rpm}$ for $3 \mathrm{~h}$ at $25 \pm 1{ }^{\circ} \mathrm{C}$. Siltered (Whatman No. 1) at 300 lyophilized and stored at $4{ }^{\circ} \mathrm{C}$.

The extraction was carried out by means of a stirrer in a water bath at $40^{\circ} \mathrm{C}$ for $1 \mathrm{~h}$. Filtered and evaporated at a temperature of $40^{\circ} \mathrm{C}$.

$25 \mathrm{~g}$ of sample was mixed with distilled water and whe extract was then filtered (Whatman No. 1) and concentrated in a rotary evaporator and finally lyophilized.

$10 \mathrm{~g}$ of sample was placed in $40 \mathrm{~mL}$ of methanol at a ratio of 1: $4(\mathrm{w} / \mathrm{v})$ using an orbital shaker, then filtered through filter paper. The residue was re-extracted and filtered.

The vegetable sample was extracted at a ratio of $1: 3(\mathrm{w} / \mathrm{v})$ for $1 \mathrm{~h}$ at $40 \pm 1{ }^{\circ} \mathrm{C}$. then filtered through filter paper (Whatman No. 1) and the supernatant was re-extracted with fresh solvent following the above procedure. Subsequently, the extract was concentrated in a rotary evaporator.
$5 \mathrm{~g}$ of sample was placed in $50 \mathrm{~mL}$ of $80 \%(\mathrm{v} / \mathrm{v})$ methanol means of a rotary evaporator at $50^{\circ} \mathrm{C}$. Finally it was

Annegowda et al. (2012)

Murillo et al. (2012)

Shofian et al. (2011)

Bhat et al. (2011) at a ratio of $1: 10(\mathrm{w} / \mathrm{v})$, using an orbital shaker at 150 rpm for $2 \mathrm{~h}$ at room temperature. The extract was filtered (Whatman No. 1) and evaporated at $45{ }^{\circ} \mathrm{C}$ for $1 \mathrm{~h}$. The concentrate was re-dissolved in $5 \mathrm{~mL}$ of $80 \%(\mathrm{v} / \mathrm{v})$ methanol and stored at $-80^{\circ} \mathrm{C}$.

The lyophilized samples were consecutively extracted with $100 \%$ methanol $(\mathrm{v} / \mathrm{v})$ in $1: 10(\mathrm{w} / \mathrm{v})$ ratio for $1 \mathrm{~h}$. They were subsequently filtered and evaporated by means of a rotary evaporator. The extracts were stored in airtight bottles and rinsed with nitrogen gas. They were then stored at $-20 \pm 1{ }^{\circ} \mathrm{C}$.

$50 \mathrm{~g}$ of sample was placed in $80 \%(\mathrm{v} / \mathrm{v})$ methanol at a ratio of $1: 3(\mathrm{w} / \mathrm{v})$ with stirring for $24 \mathrm{~h}$ at room temperature. The extract was filtered and then centrifuged at 8,000 rpm for $15 \mathrm{~min}$ and the supernatant was used for subsequent analyzes.
Zainudin et al. (2012)

Batiston et al. (2013)

Lim \& Lee (2013)

Zainudin et al. (2014)

Adiyaman et al. (2016)

DM: dry matter; FM: fresh matter; NR: not reported. Results presented as reported by the authors. 
Table 3. Continued...

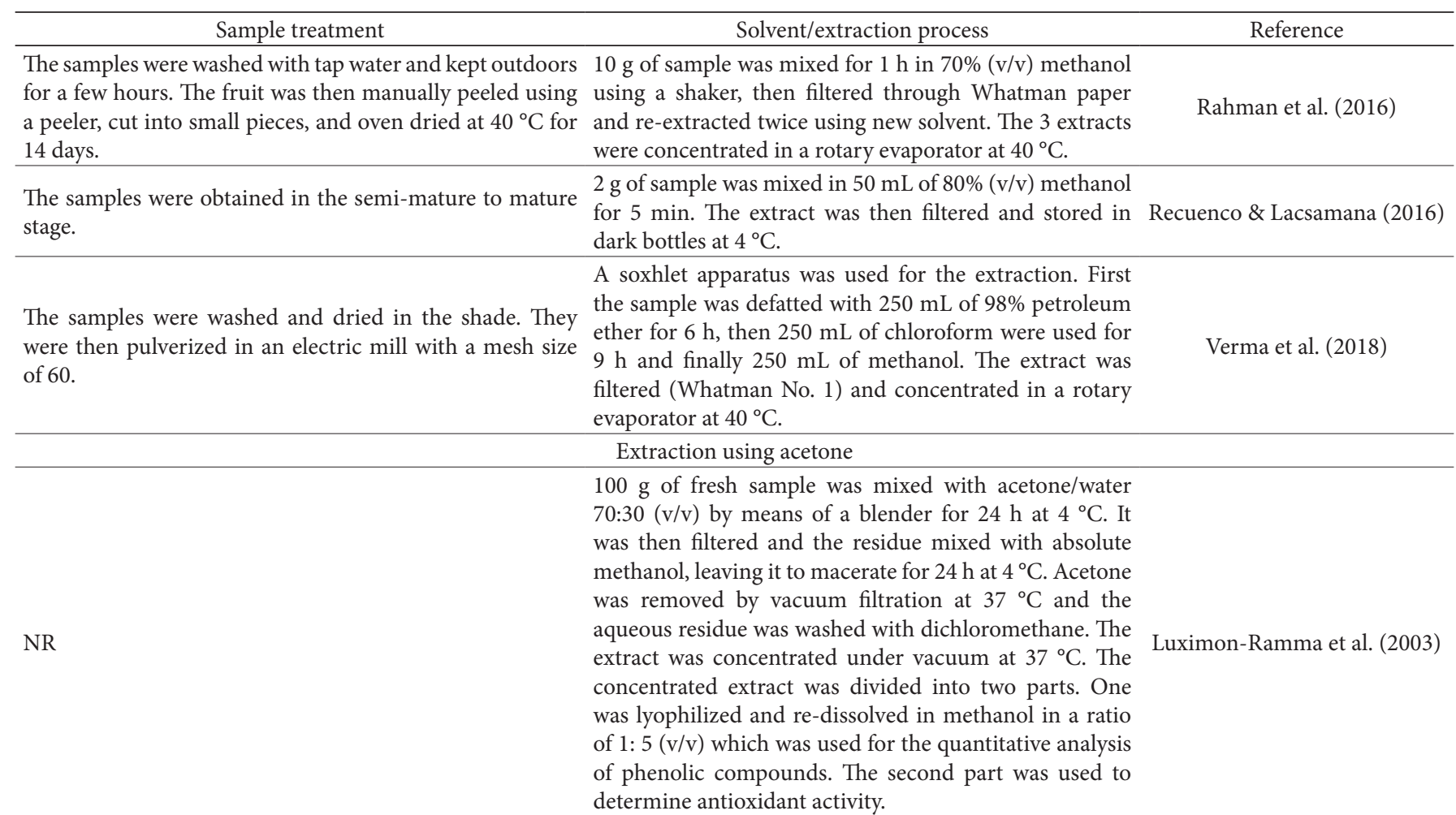

The samples were homogenized in a blender, then Different proportions of mixtures of solvents water/ centrifuged and filtered. The liquid portion (juice) was used acetone and water/ethanol (0,30, 50, 70, 100\%) were directly for the total antioxidant capacity and phenolic. used, as well as temperatures: $30,50,70,90{ }^{\circ} \mathrm{C}$ and Shui \& Leong (2006) The solid portion (residue) was dried in a lyophilizer. extraction times: $15,30,45,60 \mathrm{~min}$.

For the extraction of free phenolic compounds, $25 \mathrm{~g}$ was mixed in $80 \mathrm{ml} 80 \%$ acetone for $5 \mathrm{~min}$. Subsequently, the extract was centrifuged at 2,500 g for $10 \mathrm{~min}$. The entire process was carried out twice. The supernatants obtained were combined and filtered through No. 1 filter paper, the extract was

The samples were obtained from four cultivars: Hong from Zhanjiang; Taiguo from Guangzhou Park; Honglong and Xiangmi from Huazhou; and Shantou from cities in Guangdong province. They were chosen with the same degree of maturity and stored at $-20^{\circ} \mathrm{C}$.
For the extraction of bound phenolic compounds, the residues from the previous extraction were digested for $90 \mathrm{~min}$, stirring at room temperature using $50 \mathrm{~mL}$ of sodium hydroxide together with a stream of nitrogen. The digested sample was acidified with hydrochloric acid ( $\mathrm{pH}$ 2) and extracted five times with ethyl acetate, followed by contraction of the extract in a rotary evaporator at $45{ }^{\circ} \mathrm{C}$. The rotavaporated extracts were diluted with $5 \mathrm{~mL}$ of distilled water and stored at $40^{\circ} \mathrm{C}$.
Pang et al. (2016)

Extraction using diethyl ether

$20 \mathrm{~mL}$ of diethyl ether was used and the remaining solution was stored at $-20{ }^{\circ} \mathrm{C}$ for one day. It was subsequently centrifuged at $9,000 \mathrm{rpm}$ for $10 \mathrm{~min}$, the supernatant transferred to a separating funnel and 3 extractions were made with $20 \mathrm{~mL}$ of this The samples were peeled and liquefied to be stored at $4{ }^{\circ} \mathrm{C}$. solvent. Anhydrous sodium sulfate (spatula tip) was added to the organic extract, then filtered and passed through a rotary evaporator at $30^{\circ} \mathrm{C}$. The extract was mixed with methanol/water (1:1) and then filtered through a $0.20 \mu \mathrm{m}$ membrane and analyzed by chromatography. 
Table 3. Continued...

\begin{tabular}{cc}
\hline Sample treatment & Solvent/extraction process \\
\hline
\end{tabular}

The samples were washed, then the juice of the sample was obtained by means of a domestic juicer. The juice was filtered through a muslin cloth and divided into five batches. The authors analyzed:

1. Fresh juice.

2. Conventional juice, thermally pasteurized: $100 \mathrm{~mL}$ of freshly squeezed juice was heated in a glass tube in a thermostatic water bath at $75^{\circ} \mathrm{C}$ for $3 \mathrm{~h}$.

Saikia et al. (2016)

3 and 4. Microwave pasteurized juice (M600W and M900W): $20 \mathrm{~mL}$ of pasteurized juice was heated at 600 and 900 $\mathrm{W}$ for $30 \mathrm{~s}$ in a microwave oven at 75 and $80{ }^{\circ} \mathrm{C}$, respectively.

5. Sonicated juice: $100 \mathrm{~mL}$ of freshly squeezed juice were sonicated in an ultrasound bath (100 watt power and $30 \pm 3 \mathrm{KHz}$ frequency) for $30 \mathrm{~min}$ at $50 \pm 1{ }^{\circ} \mathrm{C}$, then all batches were cooled to $30^{\circ} \mathrm{C}$ and stored at $-20^{\circ} \mathrm{C}$.

\begin{tabular}{l} 
The samples were washed under running water and dried on tissue paper. The edible part was manually separated \\
with a stainless steel knife, crushed in a mixer and filtered manually with a cloth and 100 mesh; 0.15 mm diameter. A \\
juice was obtained and this was used to carry out the analysis of the compounds of interest. \\
Samples from two cultivars (Arkin and Honey sweet) were analyzed and washed with running tap water followed by \\
distilled water. Then they were cut into $0.5 \mathrm{~cm}$ pieces to be homogenized. They used three drying methods: by means \\
of an oven, a dehydrator and in the sun. The samples dried in the oven and by means of the dehydrator were kept at \\
$65^{\circ} \mathrm{C}$ for $4 \mathrm{~h}$. The sun-dried samples were kept for 2 days. \\
The samples were obtained for uniformity of color and degree of maturity. They were disinfected and manually \\
peeled, after which they were crushed and stored at $-80^{\circ} \mathrm{C}$. \\
The sample was baked for 2 weeks until it matured, then the vegetable matter was cleaned and mixed in a fine \\
homogenizer. The fiber and seeds were removed from the juice obtained by means of filtration through a filter cloth. \\
The juice was then freeze dried and refrigerated in a dark bottle. \\
\hline DM: dry matter; FM: fresh matter; NR: not reported. Results presented as reported by the authors.
\end{tabular}

DM: dry matter; FM: fresh matter; NR: not reported. Results presented as reported by the authors.

with $100 \mathrm{~mL}$ of the solvent until obtaining a crystalline extract. Subsequently, the extracts were filtered through filter paper, and concentrated in a rotary evaporator at $70^{\circ} \mathrm{C}$. The concentrated extracts were then lyophilized and stored in hermetic containers at $4{ }^{\circ} \mathrm{C}$. These authors carried out the same procedure with the methanolic extract. Khanam et al. (2015) used a solid solvent ratio of 1:2 (w/v) in a water bath for $24 \mathrm{~h}$. Subsequently, the extractant solution was filtered through filter paper and concentrated under reduced pressure in a rotary evaporator at $40^{\circ} \mathrm{C}$. Finally, the extract was stored at $4{ }^{\circ} \mathrm{C}$. This procedure was also used in preparing the ethanolic extract. Abdullah \& Noriham (2014) on the other hand, used a ratio of $1: 30(\mathrm{w} / \mathrm{v})$ and an extraction time of $10 \mathrm{~min}$. Subsequently, the extract was filtered through filter paper and concentrated in a rotary evaporator at $70^{\circ} \mathrm{C}$, and finally the concentrated extract was stored at $4{ }^{\circ} \mathrm{C}$ in amber bottles. Chauhan \& Kapfo (2016) performed two extractions: in the first they mixed $200 \mathrm{~g}$ of a sun-dried sample in $500 \mathrm{~mL}$ of $60 \%(\mathrm{v} / \mathrm{v})$ water (water/acetone). In the second extraction, they mixed 2,000 $\mathrm{g}$ of shade-dried sample in $5,000 \mathrm{~mL}$ of $60 \%(\mathrm{v} / \mathrm{v})$ water (water/acetone). Both solutions were stirred for $3 \mathrm{~h}$ at room temperature $\left(30^{\circ} \mathrm{C}\right)$ then filtered and the solvent consequently removed in a rotary evaporator. The dry residue of the extracts was collected and used for the antioxidant capacity tests.

\subsection{Extraction using ethanol and mixed polar solvents}

In the study by Leong \& Shui (2002) prior to extraction, the authors homogenized the sample in a blender. This sample was placed in a centrifuge tube in which $25 \mathrm{~mL}$ of $50 \%$ (v/v) hydro- alcoholic solvent (HPLC grade water) with a 1:10 (w/v) ratio has been added. The extraction was performed by a sonicator; it was also mixed by vortex for $60 \mathrm{~s}$. The extract was then centrifuged at 2,000 $\mathrm{g}$ for $5 \mathrm{~min}$ at room temperature, and finally filtered. Lim et al. (2007) mentioned that after homogenization, the sample was mixed in $100 \mathrm{~mL}$ of $50 \%$ (v/v) hydro-alcoholic solvent with manual agitation or with vibration for $10 \mathrm{~min}$. After the extract was vacuum filtered and centrifuged, the supernatant was finally stored at $-20^{\circ} \mathrm{C}$. Muñoz-Jáuregui et al. (2007) mentioned extraction of the fresh sample with $60 \%$ $(\mathrm{v} / \mathrm{v})$ ethanol followed by evaporation of the solvent in a rotary evaporator. But they did not refer to the solid/solvent ratio or the process for purifying the extract. Ali et al. (2010) performed their extraction using a 1:2 (w/v) ratio with $50 \%(\mathrm{v} / \mathrm{v})$ ethanol at room temperature for $30 \mathrm{~min}$ and with occasional stirring. The extract was then centrifuged at 2,000 g for $15 \mathrm{~min}$ and the supernatant used for the analyses. Yan et al. (2013) used a ratio of $1: 25(\mathrm{w} / \mathrm{v})$ in $50 \mathrm{~mL}$ of $70 \%$ ethanol with stirring at $200 \mathrm{rpm}$ for $2 \mathrm{~h}$ at $50^{\circ} \mathrm{C}$. Subsequently, the extract was centrifuged at $3,000 \mathrm{rpm}$ for $15 \mathrm{~min}$ at room temperature and the supernatant stored at $-20{ }^{\circ} \mathrm{C}$ for the different analyses. In another study, Saikia et al. (2015) prepared an extract with acidified ethanol $(1 \% 1 \mathrm{~N}$ hydrochloric acid, $\mathrm{pH} 3.0)$ at a ratio of $1: 10(\mathrm{w} / \mathrm{v})$ with different percentages of solvent, and different temperatures (Table 3). The extract was stirred for $3 \mathrm{~h}$ and the extracting solution was then centrifuged at 3,000 rpm for $15 \mathrm{~min}$. Finally, Guevara et al. (2019) carried out a hydro-alcoholic extraction, but did not mention the methodology. 


\subsection{Extraction using methanol and mixed polar solvents}

Mahattanatawee et al. (2006) used a 1: $4(\mathrm{w} / \mathrm{v})$ ratio with absolute methanol, mixing in a blender for $1 \mathrm{~min}$. The extract was then filtered and the residue re-extracted and filtered. Finally, the extracts were combined and concentrated in a rotavaporator at $40^{\circ} \mathrm{C}$. Bhat et al. (2011) used a ratio of $1: 10(\mathrm{w} / \mathrm{v})$ for extraction, stirring at $1,100 \mathrm{rpm}$ for $3 \mathrm{~h}$ and at $25 \pm 1^{\circ} \mathrm{C}$ followed by filtering and centrifugation at $3,000 \mathrm{~g}$ for $15 \mathrm{~min}$. The supernatant was concentrated in a rotary evaporator at $50{ }^{\circ} \mathrm{C}$. Subsequently, the extract was lyophilized and stored at $4^{\circ} \mathrm{C}$. Shofian et al. (2011) mentioned only mixing the lyophilized sample with absolute methanol; filtering the extractant solution and re-extracting twice more using fresh solvent. Finally, the three extracts were concentrated in a rotary evaporator. Annegowda et al. (2012) meanwhile performed the extraction with an ultrasound using a ratio of 1:10 (w/v) at different extraction times: 15, 30, 45, $60 \mathrm{~min}$, at room temperature $\left(25 \pm 1^{\circ} \mathrm{C}\right)$ and under low light conditions. After extraction, the sample residues were subjected to a second extraction following the same methodology, until obtaining a crystalline extract. The extracts were then filtered and concentrated in a rotary evaporator, and finally the concentrated extracts were lyophilized. Murillo et al. (2012) used an orbital shaker to mix the sample in methanol, at a 1:4 (w/v) ratio for $1 \mathrm{~h}$ at room temperature. Then, the extract was filtered using filter paper, and the residue obtained was re-extracted and filtered again. Zainudin et al. (2012) put the sample to macerate with methanol for $1 \mathrm{~h}$ at $40 \pm 1{ }^{\circ} \mathrm{C}$ using a 1:3 (w/v) ratio. Subsequently, the extract was filtered through filter paper and the sample residue was re-extracted as mentioned above. The extracts were concentrated in a rotary evaporator and finally stored at $-20 \pm 1{ }^{\circ} \mathrm{C}$. Batiston et al. (2013) used a 1:10 (w/v) sample-methanol ratio, stirring constantly for $4 \mathrm{~h}$ under low light conditions. Subsequently, the extract was filtered and the solvent evaporated in a rotary evaporator. Lim \& Lee (2013) performed the extraction with $80 \%$ methanol $(\mathrm{v} / \mathrm{v})$ by means of an orbital shaker, at a ratio of 1:10 (w/v) for $2 \mathrm{~h}$ at room temperature and at $150 \mathrm{rpm}$. The extract was filtered through filter paper and then concentrated in a rotary evaporator at $45^{\circ} \mathrm{C}$ for $1 \mathrm{~h}$. The concentrated extract was re-mixed with $80 \%(\mathrm{v} / \mathrm{v})$ methanol and stored at $-80^{\circ} \mathrm{C}$. Zainudin et al. (2014) used a ratio of 1:10 $(\mathrm{w} / \mathrm{v})$ with absolute methanol for $1 \mathrm{~h}$, performing this extraction twice consecutively. The extracts were filtered and concentrated in a rotary evaporator. The concentrated extracts were placed in airtight amber bottles, adding nitrogen and storing at $-20{ }^{\circ} \mathrm{C}$. Adiyaman et al. (2016) used a rotary agitator and a ratio of $1: 3(\mathrm{w} / \mathrm{v})$ with $80 \%$ methanol for $24 \mathrm{~h}$ at room temperature, then filtered the extract and centrifuged it at 8,000 rpm for $15 \mathrm{~min}$. The supernatant was used for the different tests. Rahman et al. (2016) mixed $10 \mathrm{~g}$ of plant sample with $70 \%$ methanol, stirring for $1 \mathrm{~h}$. The extractant solution was filtered through filter paper and re-extracted twice more using fresh solvent. The extracts obtained were concentrated in a rotary evaporator at $40{ }^{\circ} \mathrm{C}$. Recuenco \& Lacsamana (2016) mixed the vegetable sample with $80 \%$ methanol in a blender using a ratio of 1:25 (w/v) for $5 \mathrm{~min}$. The extract was then filtered and finally stored at $4{ }^{\circ} \mathrm{C}$ in dark bottles. Verma et al. (2018) performed the extraction using a soxhlet apparatus. The vegetable sample was first defatted with $250 \mathrm{~mL}$ of $98 \%$ petroleum ether for $6 \mathrm{~h}$, followed by $250 \mathrm{~mL}$ of chloroform for $9 \mathrm{~h}$ and $250 \mathrm{~mL}$ of methanol. Subsequently, the methanolic fraction was filtered through filter paper and concentrated in a rotary evaporator at $40{ }^{\circ} \mathrm{C}$, and finally the extract was stored at $4{ }^{\circ} \mathrm{C}$.

\subsection{Extraction using other solvents}

Some authors carried out the extraction of phenolic compounds and A. carambola L. using other solvents. LuximonRamma et al. (2003) mixed $100 \mathrm{~g}$ of sample in $70 \%$ acetone (v/v) using a blender and leave it to macerate for $24 \mathrm{~h}$ at $4{ }^{\circ} \mathrm{C}$. Acetone was removed from the extract by vacuum filtering at $37^{\circ} \mathrm{C}$. The aqueous extract was washed with dichloromethane $(3 \times 150 \mathrm{~mL})$ to remove fat-soluble substances. Subsequently, the extract was concentrated at $37^{\circ} \mathrm{C}$ and divided into two aliquots. The first aliquot was lyophilized and this was dissolved in methanol using a ratio of 1:5 (w/v) and the result was used to determine phenolic compounds. The second aliquot was used to determine antioxidant capacity. Shui \& Leong (2006) obtained a juice by liquefying the sample, then lyophilized and pulverized it. They used the powder to carry out extractions with ethanol and acetone at different concentrations, temperatures and extraction times (Table 3). However, the extract analyzed in his study was an extract with acetone.

Pang et al. (2016) used the fruit from various cultivars (Table 3). They performed an extract to determine free phenolic compounds. They mixed $25 \mathrm{~g}$ of fresh sample in $80 \mathrm{~mL}$ of $80 \%$ acetone for $5 \mathrm{~min}$, then centrifuged the extract at 2,500 $\mathrm{g}$ for $10 \mathrm{~min}$. This process was then repeated. Subsequently, the supernatants were combined and filtered through filter paper, and concentrated at $45^{\circ} \mathrm{C}$. The concentrated extract was mixed with $25 \mathrm{~mL}$ of distilled water and thus stored at $-40^{\circ} \mathrm{C}$. The residues obtained in this extraction were used to extract bound phenolic compounds. Those residues were digested by stirring for 90 $\mathrm{min}$ at room temperature. These authors used $50 \mathrm{~mL}$ of sodium hydroxide and a stream of nitrogen. Subsequently, the sample was acidified to a $\mathrm{pH}$ of 2 with hydrochloric acid and extracted 5 times with ethyl acetate; these were evaporated at $45^{\circ} \mathrm{C}$. The concentrated extract was mixed with $5 \mathrm{~mL}$ of distilled water and stored at $-40{ }^{\circ} \mathrm{C}$. Esteban Muñoz et al. (2018) used $20 \mathrm{~mL}$ of diethyl ether to extract the compounds; the extract was stored at $-20^{\circ} \mathrm{C}$ for $24 \mathrm{~h}$. It was then centrifuged at 9,000 rpm for $10 \mathrm{~min}$. The supernatant was separated in a funnel and three extractions were generated with $20 \mathrm{~mL}$ of diethyl ether, anhydrous sodium sulfate was added to the extract. Subsequently, it was filtered and concentrated in a rotary evaporator at $30^{\circ} \mathrm{C}$. The concentrated extracts were mixed with 1:1 methanol-water $(\mathrm{v} / \mathrm{v})$ followed by filtration through a $0.20 \mu \mathrm{m}$ membrane to introduce it to the chromatographic system.

\subsection{Extraction without the use of solvents}

Thomas et al. (2016) used only the fresh juice of the $A$. carambola $L$. fruit to determine TPC content. Saikia et al. (2016) used different methods to extract the compounds of interest from the fruit juice. They extracted $100 \mathrm{~mL}$ of the fruit juice in a water bath at $75^{\circ} \mathrm{C}$ for $3 \mathrm{~h}$. Using a microwave, they heated $25 \mathrm{~mL}$ of fruit juice to $600 \mathrm{w}$ and $900 \mathrm{~W}\left(75^{\circ} \mathrm{C}\right.$ and $\left.80^{\circ} \mathrm{C}\right)$ for 30 seconds. They also used ultrasound (100-watt power and 
$30 \pm 3 \mathrm{KHz}$ frequency) in which they placed $100 \mathrm{~mL}$ of the fruit juice for $30 \mathrm{~min}$ at $50 \pm 1^{\circ} \mathrm{C}$. Finally, all batches were stored at $-20^{\circ} \mathrm{C}$.

Most of the extraction methods are conventional methods, except those used by Leong \& Shui (2002), Annegowda et al. (2012), and Saikia et al. (2016) who use unconventional methods (sonicator, microwave) and obtained more reliable results those from conventional methods. The advantage of unconventional methods is that less time and solvent are needed to perform the extraction, and they result in a greater quantity of bioactive compounds (Rocchetti et al., 2019). On the other hand, in each extraction methodology there are variables-time, temperature, the concentration of solvents and the solid/solvent ratio-that differ from one study to the next. All of these are variables may intervene in obtaining phenolic compounds and make it difficult to draw direct comparisons between the results (Soto-García \& Rosales-Castro, 2016).

\section{Phenolic compounds present in A. carambola $L$.}

Table 4 describes the phenolic compounds found in the fruit of $A$. carambola $L$. and reported by different authors, using the fresh fruit juice and solvents such as: water, ethanol, methanol and acetone.

Annegowda et al. (2012) determined the amount of total phenolic compounds (TPC) and total flavonoid content (TFC) in aqueous and methanolic extracts. The optimal time for aqueous extraction was reported at $15 \mathrm{~min}$ with $58.8 \pm 0.60 \mathrm{mg}$ gallic acid equivalents (GAE)/g in TPC and $27.6 \pm 0.13 \mathrm{mg}$ catechin equivalents (CE)/g in TFC. On the other hand, the optimal time for the methanolic extract was $30 \mathrm{~min}$, with values of $142.0 \pm$ $0.25 \mathrm{mg} \mathrm{GAE} / \mathrm{g}$ of TPC and $79.7 \pm 2.09 \mathrm{mg} \mathrm{CE} / \mathrm{g}$ of TFC. After the optimal extraction time, the concentrations of phenolic compounds decreased for both extracts, probably due to oxidation (Tanase et al., 2019). Abdullah \& Noriham (2014) for their part, performed aqueous extracts and compare the TPC and TFC of two types of A. carambola L. (tart-type and honey-type). The tart-type fruit contains a higher concentration of oxalic acid and its flavor is sour. The honey-type fruit contains a lower concentration of oxalic acid, is larger and its flavor is milder. The fruit were also classified by maturation stage ( 3 or 4$)$. The authors reported a higher concentration in the tart-type stage 4 fruit, with $89.50 \pm 0.76 \mathrm{mg} \mathrm{GAE} / \mathrm{g}$ in TPC and $48.61 \pm 0.25 \mathrm{mg}$ $\mathrm{QE} / \mathrm{g}$ in TFC. This study reported the greatest amount of phenolic compounds in aqueous extract. Khanam et al. (2015) determined the concentration of TPC and TFC in aqueous and ethanolic extracts. They reported a higher concentration of phenolic compounds in ethanolic extract with values of $97.16 \pm 4.29 \mathrm{mg} \mathrm{GAE} / \mathrm{g}$ of dry weight (DW) in TPC; and 42.70 $\pm 1.47 \mathrm{mg}$ quercetin equivalents (QE)/g DW in TFC, compared to the aqueous extract with $77.00 \pm 2.89 \mathrm{mg} \mathrm{GAE} / \mathrm{g} \mathrm{DW}$ in TPC and $18.18 \pm 1.00 \mathrm{mg} \mathrm{QE} / \mathrm{g}$ DW in TFC. This is probably due to the chemical structure of the compounds and their affinity to the solubility and polarity of the solvent (Złotek et al., 2015). However, the TPC concentration of the aqueous extract was similar to that reported by Abdullah \& Noriham (2014) in tart-type stage 3 fruit, with $79.38 \pm 1.53 \mathrm{mg} \mathrm{GAE} / \mathrm{g}$. Chauhan \& Kapfo (2016) obtained $2.3 \pm 0.7 \mathrm{~g} \mathrm{GAE} / 100 \mathrm{~g}$ and $1.0 \pm 0.7 \mathrm{~g}$
GAE/100 $\mathrm{g}$ of TPC in fresh and dry matter respectively. These authors reported the lowest concentration of TPC in aqueous extract compared to the other studies.

In ethanolic extracts, Lim et al. (2007) analyzed the TPCs of the A. carambola $L$. fruit, among other tropical fruits from Malaysia, reporting $131 \pm 54 \mathrm{mg}$ GAE/100 g of fresh weight (FW) in the A. carambola $L$. fruit. The results were similar to that obtained in common guava (Psidium guajava), with 138 $\pm 31 \mathrm{mg} \mathrm{GAE} / 100 \mathrm{~g} \mathrm{FW}$, and higher than other tropical fruits such as the dragon fruit (Hylocereus undatus) and banana (Musa sapientum). In another study, Muñoz-Jáuregui et al. (2007) reported TPC concentrations of A. carambola $L$. and other fruits of Peru. They obtained a result of $75.97 \mathrm{mg} \mathrm{GAE} / 100 \mathrm{~g}$ FW in the fruit of $A$. carambola L. Similar results were obtained from other fruits, such as yacón (Smallanthus sonchifolius) with $67.64 \mathrm{mg}$ GAE/100 g FW. However, the TPC concentration determined by these authors in the fruit of A. carambola L. was lower than that reported by Lim et al. (2007). Guevara et al. (2019) also analyzed the fruit of A. carambola $L$. and other fruits from coastal areas of Ecuador. The concentrations found in the fruit of A. carambola $L$. were $4280.83 \pm 673.83 \mathrm{mg} \mathrm{GAE} / 100 \mathrm{~g} \mathrm{FW}$ and $48.52 \pm 5.4 \mathrm{mg}$ $\mathrm{CE} / \mathrm{g}$ FW of TPC and TFC, respectively. The differences in the concentrations of phenolic compounds may be due to various factors, such as the agro-climatic conditions of each location, the maturity of the plant sample, post-harvest treatment, as well as extraction methodologies, the proportion of solvents and the solid-solvent ratio (Ben Ghorbal et al., 2018; Mahmood et al. 2012). Yan et al. (2013) analyzed another variety of the fruit, Averrhoa bilimbi L. (A. bilimbi L.) along with A. carambola L., finding a higher concentration of TPC in A. carambola L. with $1296.25 \pm 14.74 \mathrm{mg} \mathrm{GAE} / 100 \mathrm{~g}$ DW than in A. bilimbi L. with $629.17 \pm 14.38 \mathrm{mg} \mathrm{GAE} / 100 \mathrm{~g}$ DW and a lower concentration of TFC in A. carambola L., with $66.64 \pm 13.41 \mathrm{mg}$ Rutin/100 g DW compared to $A$. bilimbi $L$. with values of $153.38 \pm 8.02 \mathrm{mg}$ Rutin/100 g DW. The TPC and TFC results obtained in $A$. carambola $L$. were superior to those reported by Khanam et al. (2015) and also higher than obtained by Ali et al. (2010) with $54.45 \pm 0.43 \mathrm{mg} \mathrm{GAE} / 100 \mathrm{mg}$ of fruit of TPC. The study carried by Saikia et al. (2015) reported values from $2222.50 \pm 0.34$ to $2287.50 \pm 0.31 \mathrm{mg} \mathrm{GAE} / 100 \mathrm{~g}$ of TPC, obtaining the highest concentration at $40{ }^{\circ} \mathrm{C}$ and with $65 \%(\mathrm{v} / \mathrm{v})$ of solvent.

The extraction of bioactive compounds depends on their solubility and the polarity of the solvent. There are other elements in the plant matrix as well that interfere in the extraction process. It has been observed, for example, that acidified solvents cause hydrolysis of these components of the plant matrix (Kopjar et al., 2014).

In methanolic extracts Shofian et al. (2011) analyzed fresh and lyophilized vegetable sample, reporting a higher amount of TPC in fresh matter, with values of $181.71 \pm 8.83 \mathrm{mg} \mathrm{GAE} / 100 \mathrm{~g}$, compared to $137.95 \pm 4.31 \mathrm{mg}$ GAE$/ 100 \mathrm{~g}$ in the lyophilized extract. These results show a higher TPC compared to other fruits found in Malaysia such as mango (mangifera indica L.), papaya (carica papaya L.), muskmelon (cucumis melo), and watermelon citruluss lanatus (Thunb.). On the other hand, a study by Recuenco \& Lacsamana (2016) also analyzed fresh and dried fruit, but obtained a higher concentration of both TPC and TFC 
Review Article

Vargas-Madriz et al.

Table 4. Report of phenolic compounds from the fruits of A. carambola $L$.

\begin{tabular}{|c|c|c|c|}
\hline Solid-solvent ratio & \% Solvent & Phenolic compounds reported & Reference \\
\hline \multicolumn{4}{|c|}{ Extraction using water } \\
\hline $1: 10(\mathrm{w} / \mathrm{v})$ & $100 \%$ & TPC: $60.5 \pm 0.55 \mathrm{mg} \mathrm{GAE} / \mathrm{g}$, TFC: $28.8 \pm 0.35 \mathrm{mg} \mathrm{CE} / \mathrm{g}$ in $0 \mathrm{~min}$ & Annegowda et al. (2012) \\
\hline & & TPC: $58.8 \pm 0.60 \mathrm{mg} \mathrm{GAE} / \mathrm{g}$, TFC: $27.6 \pm 0.13 \mathrm{mg} \mathrm{CE} / \mathrm{g}$ in $15 \mathrm{~min}$ & \\
\hline & & TPC: $58.5 \pm 1.15 \mathrm{mg} \mathrm{GAE} / \mathrm{g}$, TFC: $26.4 \pm 0.35 \mathrm{mg} \mathrm{CE} / \mathrm{g}$ in $30 \mathrm{~min}$ & \\
\hline & & TPC: $55.3 \pm 0.57 \mathrm{mg} \mathrm{GAE} / \mathrm{g}$, TFC: $26.8 \pm 0.61 \mathrm{mg} \mathrm{CE} / \mathrm{g}$ in $45 \mathrm{~min}$ & \\
\hline \multirow{9}{*}{$1: 30(\mathrm{w} / \mathrm{v})$} & & TPC: $56.9 \pm 0.71 \mathrm{mg} \mathrm{GAE} / \mathrm{g}$, TFC: $27.2 \pm 0.48 \mathrm{mg} \mathrm{CE} / \mathrm{g}$ in $60 \mathrm{~min}$. & \\
\hline & $100 \%$ & TPC: $72.42 \pm 2.98 \mathrm{mg} \mathrm{GAE} / \mathrm{g}$, stage 3 of honey-type maturity & Abdullah \& Noriham (2014) \\
\hline & & TPC: $87.65 \pm 2.57 \mathrm{mg} \mathrm{GAE} / \mathrm{g}$, stage 4 of honey-type maturity & \\
\hline & & TPC: $79.38 \pm 1.53 \mathrm{mg} \mathrm{GAE} / \mathrm{g}$, stage 3 of tart-type maturity & \\
\hline & & TPC: $89.50 \pm 0.76 \mathrm{mg} \mathrm{GAE} / \mathrm{g}$, stage 4 of tart-type maturity & \\
\hline & & TFC: $26.60 \pm 0.82 \mathrm{mg} \mathrm{QE} / \mathrm{g}$, stage 3 of honey-type maturity & \\
\hline & & TFC: $41.63 \pm 0.25 \mathrm{mg} \mathrm{QE} / \mathrm{g}$, stage 4 of honey-type maturity & \\
\hline & & TFC: $34.26 \pm 1.73 \mathrm{mg} \mathrm{QE} / \mathrm{g}$, stage 3 of tart-type maturity & \\
\hline & & TFC: $48.61 \pm 0.25 \mathrm{mg} \mathrm{QE} / \mathrm{g}$, stage 4 of type-tart maturity & \\
\hline $1: 2(\mathrm{w} / \mathrm{v})$ & NR & TPC: $77.00 \pm 2.89 \mathrm{mg}$ GAE/g DW, TFC: $18.18 \pm 1.00 \mathrm{mg}$ QE/g DW & Khanam et al. (2015) \\
\hline $2: 5(\mathrm{w} / \mathrm{v})$ & $60 \%$ & TPC: $2.3 \pm 0.7 \mathrm{~g}$ GAE$/ 100 \mathrm{~g}$ FM and $1.0 \pm 0.7 \mathrm{~g} \mathrm{GAE} / 100 \mathrm{~g}$ DM. & Chauhan \& Kapfo (2016) \\
\hline \multicolumn{4}{|c|}{ Extraction using ethanol } \\
\hline NR & $50 \%$ & TPC: $131 \pm 54 \mathrm{mg} \mathrm{GAE} / 100 \mathrm{~g} \mathrm{FW}$. & Lim et al. (2007) \\
\hline NR & $60 \%$ & TPC: $75.97 \mathrm{mg} \mathrm{GAE} / 100 \mathrm{~g}$ FW. & Muñoz-Jáuregui et al. (2007) \\
\hline $1: 2(\mathrm{w} / \mathrm{v})$ & $50 \%$ & TPC: $54.45 \pm 0.43 \mathrm{mg}$ GAE$/ 100 \mathrm{mg}$ of fruit. & Ali et al. (2010) \\
\hline $1: 25(\mathrm{w} / \mathrm{v})$ & $70 \%$ & TPC: $1296.25 \pm 14.74$ mg GAE/100 g DW, TFC: $66.64 \pm 13.41$ mg Rutin/100 g DW. & Yan et al. (2013) \\
\hline $1: 10(\mathrm{w} / \mathrm{v})$ & $\mathrm{HCl} 1 \mathrm{~N}$ & TPC: $2222.50 \pm 0.34$ hasta $2287.50 \pm 0.31 \mathrm{mg} \mathrm{GAE} / 100 \mathrm{~g}$. & Saikia et al. (2015) \\
\hline $1: 2(\mathrm{w} / \mathrm{v})$ & NR & TPC: $97.16 \pm 4.29 \mathrm{mg}$ GAE/g DW, TFC: $42.70 \pm 1.47 \mathrm{mg}$ QE/g DW & Khanam et al. (2015) \\
\hline NR & NR & TPC: $4280.83 \pm 673.83 \mathrm{mg}$ GAE/100 g FW, TFC: $48.52 \pm 5.4 \mathrm{mg}$ CE/g FW. & Guevara et al. (2019) \\
\hline \multicolumn{4}{|c|}{ Extraction using methanol } \\
\hline $1: 4(\mathrm{w} / \mathrm{v})$ & $100 \%$ & TPC: $2207.7 \pm 156.7 \mu \mathrm{g}$ GAE/g puree FW. & Mahattanatawee et al. (2006) \\
\hline $1: 10(\mathrm{w} / \mathrm{v})$ & NR & TPC: $0.65 \pm 0.06 \mathrm{mg} \mathrm{GAE} / \mathrm{g}$, TFC: $2.32 \pm 0.01 \mathrm{mg} \mathrm{QE} / 100 \mathrm{~g}$ in $0 \mathrm{~min}$ & Bhat et al. (2011) \\
\hline & & TPC: $0.67 \pm 0.02 \mathrm{mg} \mathrm{GAE} / \mathrm{g}$, TFC: $2.36 \pm 0.03 \mathrm{mg} \mathrm{QE} / 100 \mathrm{~g}$ in $30 \mathrm{~min}$ & \\
\hline & & TPC: $0.69 \pm 0.02 \mathrm{mg} \mathrm{GAE} / \mathrm{g}$, TFC: $2.47 \pm 0.02 \mathrm{mg} \mathrm{QE} / 100 \mathrm{~g}$ in $60 \mathrm{~min}$ & \\
\hline NR & NR & TPC: $181.71 \pm 8.83 \mathrm{mg} \mathrm{GAE} / 100 \mathrm{~g} F M$ and $137.95 \pm 4.31 \mathrm{mg} \mathrm{GAE} / 100 \mathrm{~g}$ DM. & Shofian et al. (2011) \\
\hline \multirow[t]{5}{*}{$1: 10(\mathrm{w} / \mathrm{v})$} & NR & TPC: $120.8 \pm 0.30 \mathrm{mg} \mathrm{GAE} / \mathrm{g}$, TFC: $63.8 \pm 2.24 \mathrm{mg} \mathrm{CE} / \mathrm{g}$ in $0 \mathrm{~min}$ & Annegowda et al. (2012) \\
\hline & & TPC: $122.3 \pm 1.55 \mathrm{mg} \mathrm{GAE} / \mathrm{g}$, TFC: $65.3 \pm 2.32 \mathrm{mg} \mathrm{CE} / \mathrm{g}$ in $15 \mathrm{~min}$ & \\
\hline & & TPC: $142.0 \pm 0.25 \mathrm{mg} \mathrm{GAE} / \mathrm{g}$, TFC: $79.7 \pm 2.09 \mathrm{mg} \mathrm{CE} / \mathrm{g}$ in $30 \mathrm{~min}$ & \\
\hline & & TPC: $127.0 \pm 0.62 \mathrm{mg} \mathrm{GAE} / \mathrm{g}$, TFC: $68.4 \pm 1.31 \mathrm{mg} \mathrm{CE} / \mathrm{g}$ in $45 \mathrm{~min}$ & \\
\hline & & TPC: $124.8 \pm 0.50 \mathrm{mg} \mathrm{GAE} / \mathrm{g}$, TFC: $69.3 \pm 0.61 \mathrm{mg} \mathrm{CE} / \mathrm{g}$ in $60 \mathrm{~min}$. & \\
\hline $1: 4(\mathrm{w} / \mathrm{v})$ & NR & TPC: $259.20 \mathrm{mg} \mathrm{GAE} / 100 \mathrm{~g} \mathrm{FW.}$ & Murillo et al. (2012) \\
\hline $1: 3(\mathrm{w} / \mathrm{v})$ & NR & TPC: $117.72 \pm 13.75 \mathrm{mg} \mathrm{GAE} / 100 \mathrm{~g} \mathrm{FW}$. & Zainudin et al. (2012) \\
\hline $1: 10(\mathrm{w} / \mathrm{v})$ & NR & TPC: $127.26 \pm 1.48 \mathrm{mg} \mathrm{GAE} / 100 \mathrm{~g}$ of sample. & Batiston et al. (2013) \\
\hline \multirow[t]{2}{*}{$1: 10(\mathrm{w} / \mathrm{v})$} & $80 \%$ & TPC: $16.18 \pm 1.40$ TAE/100 g FW, TFC: $7.06 \pm 0.82 \mathrm{~g}$ CE/100 g FW in UF & Lim \& Lee (2013) \\
\hline & & TPC: $39.89 \pm 5.29 \mathrm{~g}$ TAE/100 g FW, TFC: $16.01 \pm 2.07 \mathrm{~g} \mathrm{CE} / 100 \mathrm{~g}$ FW in MF & \\
\hline $1: 10(\mathrm{w} / \mathrm{v})$ & $100 \%$ & TPC: $234.89 \pm 19.85 \mathrm{mg} \mathrm{GAE} / 100 \mathrm{~g} \mathrm{FW}$, TFC: $205 \pm 4.99 \mathrm{mg} \mathrm{EE} / 100 \mathrm{~g} \mathrm{FW}$ & Zainudin et al. (2014) \\
\hline $1: 3(\mathrm{w} / \mathrm{v})$ & $80 \%$ & TPC: $161.56 \pm 9.24 \mathrm{mg} \mathrm{GAE} / 100 \mathrm{~g}$ FW, TFC: $72.00 \pm 2.69 \mathrm{mg}$ QE/100 g FW & Adiyaman et al. (2016) \\
\hline NR & $70 \%$ & TPC: $31.76 \pm 1.45 \mathrm{mg}$ GAE/g FW & Rahman et al. (2016) \\
\hline $1: 20(\mathrm{w} / \mathrm{v})$ & $80 \%$ & $\begin{array}{c}\text { TPC: } 209 \pm 15 \mathrm{mg} \mathrm{GAE} / 100 \mathrm{~g} \text { FM and } 1490 \pm 108 \mathrm{mg} \mathrm{GAE} / 100 \mathrm{~g} \mathrm{DM} \\
\text { TFC: } 101 \pm 7 \mathrm{mg} \mathrm{CE} / 100 \mathrm{~g} \mathrm{FM} \text { and } 722 \pm 53 \mathrm{mg} \mathrm{CE} / 100 \mathrm{~g} \mathrm{DM}\end{array}$ & Recuenco \& Lacsamana (2016) \\
\hline \multicolumn{4}{|c|}{ Extraction using acetone } \\
\hline NR & $70 \%$ & $\begin{array}{l}\text { TPC: } 1429 \pm 71 \mu \mathrm{g} \text { GAE/g FW, Flavonoids: } 103 \pm 11 \mu \mathrm{g} \text { QE/g FW } \\
\text { proanthocyanidins: } 896 \pm 23 \mu \mathrm{g} \text { cyanidin chloride/g FW. }\end{array}$ & Luximon-Ramma et al. (2003) \\
\hline NR & $50 \%$ & TPC: $33.2 \pm 3.6 \mathrm{mg} \mathrm{GAE} / \mathrm{g}$ on a dry basis. & Shui \& Leong (2006) \\
\hline
\end{tabular}

CE: catechin equivalents; DM: dry matter; DW: dry weight; EE: epicatechin equivalent; FJ: fresh juice; FM: fresh weight; FW: fresh weight; GAE: gallic acid equivalent; MF: mature fruit; MPJ: Microwave-pasteurized juice; NR: no reported; PJ: pasteurized juice; QE: quercetin equivalent; TAE: Tannic acid equivalent; TFC: total flavonoid content; TPC: total phenol content; SFJ: sonicated fruit juice; UF: unripe fruit. Results presented as reported by the authors. 
Table 4. Continued...

\begin{tabular}{|c|c|c|c|}
\hline Solid-solvent ratio & $\%$ Solvent & Phenolic compounds reported & Reference \\
\hline $5: 16(\mathrm{w} / \mathrm{v})$ & $80 \%$ & Free TPC: $162.5 \pm 4.9 \mathrm{mg}$ GAE/100 g FW in Honlong cultivars & Pang et al. (2016) \\
\hline & & Bound TPC: $12.0 \pm 1.1 \mathrm{mg} \mathrm{GAE} / 100 \mathrm{~g}$ FW in Honlong cultivars & \\
\hline & & Free TPC: $225.1 \pm 5.6 \mathrm{mg} \mathrm{GAE} / 100 \mathrm{~g}$ FW In Hong cultivars & \\
\hline & & Bound TPC: $16.9 \pm 0.4 \mathrm{mg}$ GAE$/ 100 \mathrm{~g}$ FW In Hong cultivars & \\
\hline & & Free TPC: $236.0 \pm 5.0 \mathrm{mg}$ GAE/100 g FW In Xiangmi cultivars & \\
\hline & & Bound TPC: $19.7 \pm 0.3 \mathrm{mg}$ GAE/100 g FW In Xiangmi cultivars & \\
\hline & & Free TPC: $286.8 \pm 2.6 \mathrm{mg}$ GAE/100 g FW In Taiguo cultivars & \\
\hline & & Bound TPC: $6.4 \pm 0.3 \mathrm{mg}$ GAE/100 g FW In Taiguo cultivars & \\
\hline & & Free TFC: $100.7 \pm 6.1 \mathrm{mg} \mathrm{CE} / 100 \mathrm{~g} \mathrm{FW}$ in Honlong cultivars & \\
\hline & & Bound TFC: $3.7 \pm 1.0 \mathrm{mg} \mathrm{CE} / 100 \mathrm{~g} \mathrm{FW}$ in Honlong cultivars & \\
\hline & & Free TFC: $125.3 \pm 2.3 \mathrm{mg}$ CE/100 g FW In Hong cultivars & \\
\hline & & Bound TFC: $4.9 \pm 0.7 \mathrm{mg}$ CE $/ 100 \mathrm{~g}$ FW In Hong cultivars & \\
\hline & & Free TFC: $186.8 \pm 17.0 \mathrm{mg}$ CE/100 g FW In Xiangmi cultivars & \\
\hline & & Bound TFC: $7.8 \pm 0.3 \mathrm{mg} \mathrm{CE} / 100 \mathrm{~g}$ FW In Xiangmi cultivars & \\
\hline & & Free TFC: $234.0 \pm 9.0 \mathrm{mg}$ CE/100 g FW In Taiguo cultivars & \\
\hline & & Bound TFC: $1.1 \pm 0.2 \mathrm{mg}$ CE/100 g FW In Taiguo cultivars & \\
\hline
\end{tabular}

Solvent free

TPC: $145.00 \pm 0.35 \mathrm{mg} \mathrm{GAE} / 100 \mathrm{~mL}$ and TFC: $23.25 \pm 0.11 \mathrm{mg} \mathrm{QE} / 100 \mathrm{~mL}$ in F

TPC: $158.00 \pm 0.30 \mathrm{mg} \mathrm{GAE} / 100 \mathrm{~mL}$ and TFC: $158.00 \pm 0.30 \mathrm{mg} \mathrm{QE} / 100 \mathrm{~mL}$ in PJ

TPC: $650.12 \pm 0.10 \mathrm{mg} \mathrm{GAE} / 100 \mathrm{~mL}$ and TFC: $21.75 \pm 0.31 \mathrm{mg} \mathrm{QE} / 100 \mathrm{~mL}$ for MPJ (600W)

TPC: $700.00 \pm 0.15 \mathrm{mg} \mathrm{GAE} / 100 \mathrm{~mL}$ and TFC: $19.25 \pm 0.12 \mathrm{mg} \mathrm{QE} / 100 \mathrm{~mL}$ for MPJ (900W)

TPC: $743.50 \pm 0.14 \mathrm{mg} \mathrm{GAE} / 100 \mathrm{~mL}$ and TFC: $35.75 \pm 0.14 \mathrm{mg} \mathrm{QE} / 100 \mathrm{~mL}$ for SFJ

TPC: $131 \pm 2.00 \mathrm{mg} \mathrm{GAE} / 100 \mathrm{~g}$

TPC: $60 \pm 0.8 \mathrm{mg} \mathrm{GAE} / \mathrm{g}$

TPC: $21.97 \pm 0.98$ and $24.92 \pm 0.98 \mathrm{mg}$ GAE$/ \mathrm{g}$ in fresh sample of Arkin and Honey sweet cultivars, respectively

Saikia et al. (2016) $4.13 \pm 0.36 \mathrm{mg} \mathrm{GAE} / \mathrm{g}$ in dehydrated
Honey sweet cultivars, respectively

in dehydrated sample of Arkin and

TPC: $6.93 \pm 0.09$ and $5.57 \pm 0.36 \mathrm{mg} \mathrm{GAE} / \mathrm{g}$ in oven-dried sample of Arkin and

Honey sweet cultivars, respectively, TPC: $2.89 \pm 0.03$ to $3.83 \pm 0.05 \mathrm{mg}$ GAE/g in sun-dried sample of Arkin and Honey sweet cultivars, respectively

TPC: $320 \pm 37.0 \mathrm{mg}$ GAE/100 g DM, TFC: $0.04 \pm 0.01 \mathrm{mg} \mathrm{QE} / 100 \mathrm{~g} \mathrm{DM}$

TPC: $5.12 \pm 0.24 \mu \mathrm{g} \mathrm{GAE} / 100 \mathrm{~g}$, TFC: $0.18 \pm 0.008 \mu \mathrm{g}$ QE/100 g

Otero et al. (2020)

Thomas et al. (2016)

Deena et al. (2017)

Ruvini et al. (2017)

Pothasak et al $(2020)$

CE: catechin equivalents; DM: dry matter; DW: dry weight; EE: epicatechin equivalent; FJ: fresh juice; FM: fresh weight; FW: fresh weight; GAE: gallic acid equivalent; MF: mature fruit; MPJ: Microwave-pasteurized juice; NR: no reported; PJ: pasteurized juice; QE: quercetin equivalent; TAE: Tannic acid equivalent; TFC: total flavonoid content; TPC: total phenol content; SFJ: sonicated fruit juice; UF: unripe fruit. Results presented as reported by the authors.

in the extract from dry matter, with values of $1490 \pm 108 \mathrm{mg}$ $\mathrm{GAE} / 100 \mathrm{~g}$ and $722 \pm 53 \mathrm{mg}$ EC/100 g respectively; while the values reported from fresh matter extract were $209 \pm 15 \mathrm{mg}$ GAE/100 g of TPC and $101 \pm 7 \mathrm{mg}$ EC/100 $\mathrm{g}$ of TFC. Phenolic compounds were frequently in different states of union, which explains why the drying process can cause variations in TPC concentration (Chauhan \& Kapfo, 2013). Furthermore, the concentrations of phenolic compounds in A. carambola L. were higher than other fruits such as Pithecellobium dulce, Psidium guajava, and Litchi chinensi, analyzed in this study (carried out in the Philippines). Lim \& Lee (2013) analyzed TPC and TFC in mature and immature A. carambola L. samples, reporting TPC values of $16.18 \pm 1.40 \mathrm{~g}$ tannic acid equivalent $(\mathrm{TAE}) / 100$ g FW and TFC values of $7.06 \pm 0.82 \mathrm{~g}$ Catechin equivalent (CAE)/100 g FW in immature sample. Likewise, they reported
TPC values of $39.89 \pm 5.29 \mathrm{~g} \mathrm{TAE} / 100 \mathrm{~g} \mathrm{FW}$ and TFC values of $16.01 \pm 2.07 \mathrm{~g} \mathrm{CAE} / 100 \mathrm{~g}$ FW in mature sample. Similar results were reported by Abdullah \& Noriham (2014) who obtained higher values of phenolic compounds in A. carambola $L$. at the highest stage of fruit maturity. As a fruit matures, it undergoes physical and biochemical changes that may explain the higher concentration of phenolic compounds and antioxidant capacity found in most fruits in a certain state of maturity (Nobossé et al., 2018). A study by Zainudin et al. (2014) reported TPC values of $234.89 \pm 19.85 \mathrm{mg} \mathrm{GAE} / 100 \mathrm{~g} \mathrm{FW}$ and TFC values of $205 \pm 4.99 \mathrm{mg}$ catechin equivalent (EE)/100 g FW. These were higher than the results obtained by Adiyaman et al. (2016) who recorded TPC values of $161.56 \pm 9.24 \mathrm{mg} \mathrm{GAE} / 100 \mathrm{~g}$ FW and TFC values of $72.00 \pm 2.69 \mathrm{mg}$ QE/100 g FW. Studies by Zainudin et al. (2012) and Batiston et al. (2013) reported similar concentrations of 
TPC with values of $117.72 \pm 13.75 \mathrm{mg} \mathrm{GAE} / 100 \mathrm{~g} \mathrm{FW}$; and $127.26 \pm 1.48 \mathrm{mg} \mathrm{GAE} / 100 \mathrm{~g}$ of sample, respectively. These results were comparable to the TPC values reported in the guava (Psidium guajava L.) with $127.54 \pm 2.01 \mathrm{mg} \mathrm{GAE} / 100 \mathrm{~g}$ of sample reported in a study by Batiston et al. (2013). Zainudin et al. (2012) did not report a significant difference in the TPC values of $A$ carambola L. samples that have been washed, cut and stored in the dark, compared to samples stored under fluorescent light for 12 days. On the other hand, before performing the methanolic extraction, Bhat et al. (2011) exposed the vegetable sample (juice) to lamps with UV light of a radiation of $2,158 \mathrm{~J} / \mathrm{m}^{2}$ (digital radiometer) for different periods of time $(0,30$ and $60 \mathrm{~min}$ ). The results showed a higher concentration of phenolic compounds at $60 \mathrm{~min}$ of UV light exposure, with TPC values of $0.69 \pm 0.02 \mathrm{mg} \mathrm{GAE} / \mathrm{g}$ and TFC of $2.47 \pm 0.02 \mathrm{mg} \mathrm{QE} / 100 \mathrm{~g}$. This may be due to the activation of the enzyme phenylalanine ammonia-lyase by exposure to UV light, causing a decrease in the activity of the enzyme polyphenol oxidase (Zainudin et al., 2012). Murillo et al. (2012) reported a higher amount of TPC than did previous studies, with values of $259.20 \mathrm{mg} \mathrm{GAE} / 100 \mathrm{~g}$ FW. But it is Rahman et al. (2016) who reported the highest concentration of TPC in the methanolic extract, with values of $31.76 \pm 1.45 \mathrm{mg} \mathrm{GAE} / \mathrm{g} \mathrm{FW}$, while Mahattanatawee et al. (2006) reported lower concentrations of TPC in methanolic extracts with $2207.7 \pm 156.7 \mu \mathrm{g} \mathrm{GAE} / \mathrm{g}$ of FW puree.

Luximon-Ramma et al. (2003) used acetone as an extraction solvent for phenolic compounds, obtaining TPC values of $1429 \pm 71 \mu \mathrm{g} \mathrm{GAE} / \mathrm{g}$ FW, flavonoid values of $103 \pm 11 \mu \mathrm{g} \mathrm{QE} / \mathrm{g}$ FW and proanthocyanidins values of $896 \pm 23 \mu \mathrm{g}$ cyanidin chloride/g FW. TPC values lower than those reported by Mahattanatawee et al. (2006) in methanolic extract. Shui \& Leong (2006) reported TPC values of $33.2 \pm 3.6 \mathrm{mg} \mathrm{GAE} / \mathrm{g}$ on a dry basis using acetone as a solvent, concentrations slightly below that reported by Guevara et al. (2019) and higher than reported by Saikia et al. (2015) in an ethanolic extract.

Pang et al. (2016) studied various cultivars and found, generally speaking, a higher amount of free TPC and TFC than bound TPC and TFC. The Taiguo cultivar yielded the highest amount of free TPC and TFC, with values of $286.8 \pm 2.6 \mathrm{mg} \mathrm{GAE} / 100 \mathrm{~g}$ $\mathrm{FW}$ and $234.0 \pm 9.0 \mathrm{mg} \mathrm{CE} / 100 \mathrm{~g} \mathrm{FW}$ respectively, following in descending order by the Xiangmi, Hong and Honglong cultivars. The highest amount of bound TPC and TFC was reported in the Xiangmi cultivar, with values of $19.7 \pm 0.3 \mathrm{mg} \mathrm{GAE} / 100 \mathrm{~g}$ FW and $7.8 \pm 0.3 \mathrm{mg} \mathrm{EC} / 100 \mathrm{~g} \mathrm{FW}$, respectively, following in descending order by the Hong, Honglong and Taiguo cultivars. Phenolic compounds can be free or linked to other components of the plant cell wall. Aqueous and organic solvents were used to extract free phenolic compounds, while phenolic compounds linked to the plant matrix cannot be extracted using this type of solvent along, so alkaline or acidic hydrolysis methods were used (Su et al., 2014). Other studies have mentioned that alkaline hydrolysis can extract more of the bound TPC than acid hydrolysis (Gao et al., 2017). However, it is essential to optimize factors such as solvents, extraction time and temperature, since these can result in a higher concentration of bound TPCs, or degradation of the compounds (Irakli et al., 2018). It is suggested that other methodologies for the hydrolysis of linked phenolic compounds be compared in future research.
Other authors used only the juice from A. carambola $L$. fruit, these included Saikia et al. (2016) who compared the amount of phenolic compounds in juice subjected to different extraction conditions. The authors reported the highest amount of TPC and TFC using an ultrasonicator with values of $743.50 \pm 0.14 \mathrm{mg} \mathrm{GAE} / 100 \mathrm{~mL}$ and $35.75 \pm 0.14 \mathrm{mg}$ QE/100 mL, respectively. Thomas et al. (2016) reported TPC values of $131 \pm 2.00 \mathrm{mg} \mathrm{GAE} / 100 \mathrm{~g}$ in the juice of $A$. carambola $L$, similar to the results reported by Saikia et al. (2016). Deena et al. (2017) meanwhile reported TPC values of $60 \pm 0.8 \mathrm{mg} \mathrm{GAE} / \mathrm{g}$, higher than that reported by the other studies. These authors did not describe their extraction methodology, however, so it is difficult to know which factors may have influenced these values. Ruvini et al. (2017) analyzed the TPC values of two cultivars (Arkin and Honey sweet), using different drying methods: by dehydrator, in a drying oven and sun-drying. They reported the greatest amount of phenolic compounds in fruit samples treated in a drying oven, with values of $6.93 \pm 0.09$ and $5.57 \pm 0.36 \mathrm{mg}$ GAE/g in cultivars Arkin and Honey sweet, respectively. These were followed by the sample dried in a dehydrator and finally the sun-dried sample. In general, however, drying was found to reduce the amount of TPC in both cultivars compared to the values reported in the fresh sample: $21.97 \pm 0.98$ and $24.92 \pm 0.98 \mathrm{mg}$ GAE/g in the Arkin and Honey sweet cultivars, respectively. As mentioned above, drying methods regularly cause the inhibition of certain microorganisms and enzymes that can degrade the compounds of interest in the plant sample. Sun-drying is carried out at room temperature for prolonged times, which results in a slow loss of humidity and a gradual inactivation of polyphenol oxidase and peroxidase enzymes, causing the degradation of compounds of interest. On the other hand, the decrease in TPC values among the different drying methods may be due to the activity of these enzymes before the variables of temperature and moisture content reach the point necessary to inactivate them (Rababah et al., 2015; Teles et al., 2018). Without using solvents, Pothasak et al. (2020) found lower values of TPC and TFC than other studies, with values of $5.12 \pm 0.24 \mu \mathrm{g}$ GAE/100 g and $0.18 \pm 0.008 \mu \mathrm{g} \mathrm{QE} / 100 \mathrm{~g}$, respectively.

\section{Antioxidant capacity of A. carambola $L$.}

In aqueous extracts, Shui \& Leong (2004) reported antioxidant capacity using the 2,2'-azino-bis (3-ethylbenzothiazoline-6-sulphonic acid) (ABTS) technique with values of $227.8 \mathrm{mg} \mathrm{L}$-ascorbic acid equivalent antioxidant capacity (VCEAC)/100 g and 293.8 mg VCEAC/100 g. (Table 5); while Annegowda et al. (2012) determined the antioxidant capacity in aqueous and methanolic extracts at different extraction times. Using the 1,1-diphenyl-2picrylhydrazyl assay (DPPH) and ferric reducing antioxidant power assay (FRAP) techniques, they reported a small increase in antioxidant capacity by both techniques in methanolic extracts at $30 \mathrm{~min}$. These authors reported $87.4 \pm 0.41 \%$ inhibition by $\mathrm{DPPH}$, and $2.4 \pm 0.00 \mathrm{Mm}$ ferric reduction to ferrous (FRF)/g by FRAP. In the aqueous extract they obtained values of 40.5 $\pm 0.96 \%$ inhibition by DPPH, and values of $1.14 \pm 0.03 \mathrm{mM}$ FRF/g by FRAP at $0 \mathrm{~min}$, and $39.6 \pm 0.35 \%$ inhibition by $\mathrm{DPPH}$ and $1.09 \pm 0.01 \mathrm{mM} \mathrm{FRF} / \mathrm{g}$ by FRAP, at $15 \mathrm{~min}$. As the extraction time passes, a decrease in antioxidant capacity was observed. Abdullah \& Noriham (2014) obtained a higher 
Table 5. Antioxidant capacity reported in fruit A. carambola $L$.

\begin{tabular}{|c|c|c|c|}
\hline Solid-solvent ratio & $\%$ Solvent & Antioxidant capacity & Reference \\
\hline \multicolumn{4}{|c|}{ Extraction using water } \\
\hline NR & $50 \%$ & ABTS: $227.8 \mathrm{mg} \mathrm{VCEAC/100} \mathrm{g}$ and $293.8 \mathrm{mg} \mathrm{VCEAC} / 100 \mathrm{~g}$ & Shui \& Leong (2004) \\
\hline $1: 10(\mathrm{w} / \mathrm{v})$ & NR & DPPH: $40.5 \pm 0.96 \%$ inhibition, FRAP: $1.14 \pm 0.03 \mathrm{mM} \mathrm{FRF} / \mathrm{g}$ in $0 \mathrm{~min}$ & Annegowda et al. (2012) \\
\hline & & DPPH: $39.6 \pm 0.35 \%$ inhibition, FRAP: $1.09 \pm 0.01 \mathrm{mM} \mathrm{FRF} / \mathrm{g}$ in $15 \mathrm{~min}$ & \\
\hline & & DPPH: $38.1 \pm 0.75 \%$ inhibition, FRAP: $1.06 \pm 0.00 \mathrm{mM}$ FRF/g in $30 \mathrm{~min}$ & \\
\hline & & DPPH: $38.0 \pm 0.43 \%$ inhibition, FRAP: $1.04 \pm 0.01 \mathrm{mM} \mathrm{FRF} / \mathrm{g}$ in $45 \mathrm{~min}$ & \\
\hline & & DPPH: $37.6 \pm 0.82 \%$ inhibition, FRAP: $1.08 \pm 0.01 \mathrm{mM} \mathrm{FRF} / \mathrm{g}$ in $60 \mathrm{~min}$ & \\
\hline $1: 30(\mathrm{w} / \mathrm{v})$ & NR & $\begin{array}{c}\text { DPPH: } 74 \% \text { inhibition (tart-type stage } 4 \text { maturity), FRAP: } 5.1023 \text { and } 5.0759 \\
\text { Mmol/TE (honey-type stage } 4 \text { maturity and type-tart stage } 4 \text { maturity, } \\
\text { respectively), } \beta \text {-Carotene bleaching activity: } 57.65 \pm 4.42 \mathrm{AOX}(\%) \text { (stage } 3 \\
\text { honey-type maturity), } 90.34 \pm 1.65 \text { AOX (\%) (honey-type stage } 4 \text { maturity), } \\
47.35 \pm 1.97 \text { AOX (\%) (tart-type stage } 3 \text { maturity), } 94.28 \pm 1.42 \text { AOX (\%) (tart- } \\
\text { type stage } 4 \text { maturity). }\end{array}$ & Abdullah \& Noriham (2014) \\
\hline $2: 5(\mathrm{w} / \mathrm{v})$ & $60 \%$ & DPPH: $100 \pm 6.2 \mathrm{IC}_{50} \mu \mathrm{g} / \mathrm{mL}$, TEAC: $0.37 \pm 0.023$ fresh fruit & Chauhan \& Kapfo (2016) \\
\hline & & DPPH: $150 \pm 3.4 \mathrm{IC}_{50} \mu \mathrm{g} / \mathrm{mL}$, TEAC: $1.05 \pm 0.005$ dried fruit & \\
\hline \multicolumn{4}{|c|}{ Extraction using ethanol } \\
\hline $1: 10(\mathrm{w} / \mathrm{v})$ & $50 \%$ & ABTS: $278 \pm 22.3 \mathrm{mg}$ VCEAC/100 g & Leong \& Shui (2002) \\
\hline NR & $50 \%$ & DPPH: $3.8 \pm 2.1 \mathrm{IC}_{50} \mathrm{mg} / \mathrm{mL}$ and $98 \pm 55 \mathrm{mg} \mathrm{VCEAC} / 100 \mathrm{~g}$ & Lim et al. (2007) \\
\hline NR & $60 \%$ & DPPH: $403.31 \mathrm{EC}_{50} \mathrm{mg} / \mathrm{mL}$, TEAC: $0.80 \mu \mathrm{mol} / \mathrm{g}$ & Muñoz-Jáuregui et al. (2007) \\
\hline $1: 2(\mathrm{w} / \mathrm{v})$ & $70 \%$ & DPPH: $81.03 \pm 1.97 \mathrm{mg} \mathrm{TE} / 100 \mathrm{mg}$ of fruit, FRAP: $78.770 \pm 0.35 \mathrm{TE} / 100 \mathrm{mg}$ of fruit & Ali et al. (2010) \\
\hline $2: 25(\mathrm{w} / \mathrm{v})$ & $70 \%$ & $\begin{array}{c}\text { DPPH: } 1.88 \pm 0.62 \mathrm{IC}_{50} \mathrm{mg} / \mathrm{mL}, \beta \text {-Carotene bleaching activity: } 47.73 \pm 5.54 \\
\text { AOX }(\%)\end{array}$ & Yan et al. (2013) \\
\hline NR & NR & DPPH: $1215.34 \pm 101.98 \mu \mathrm{mol}$ TE/g FW, FRAP: $3370.94 \pm 308.02 \mu \mathrm{mol}$ TE/g FW & Guevara et al. (2019) \\
\hline \multicolumn{4}{|c|}{ Extraction using methanol } \\
\hline $1: 4(\mathrm{w} / \mathrm{v})$ & $100 \%$ & DPPH: $620.2 \pm 40.9 \mu \mathrm{g}$ GAE/g puree and ORAC: $12.9 \pm 1.0 \mu \mathrm{g}$ TE/g puree & Mahattanatawee et al. (2006) \\
\hline $1: 10(\mathrm{w} / \mathrm{v})$ & NR & DPPH: $85.74 \pm 0.36 \%$ inhibition in $0 \mathrm{~min}$ & Bhat et al. (2011) \\
\hline \multicolumn{4}{|c|}{ DPPH: $87.27 \pm 0.28 \%$ inhibition in $30 \mathrm{~min}$} \\
\hline \multicolumn{4}{|c|}{ DPPH: $88.08 \pm 0.77 \%$ inhibition in $60 \mathrm{~min}$} \\
\hline NR & NR & DPPH: 87 and 95\% inhibition in lyophilized and fresh fruit, respectively. & Shofian et al. (2011) \\
\hline \multirow[t]{5}{*}{$10:(\mathrm{w} / \mathrm{v})$} & NR & DPPH: $68.6 \pm 1.80 \%$ inhibition, FRAP: $2.1 \pm 0.01 \mathrm{Mm} \mathrm{FRF} / \mathrm{g}$ in $0 \mathrm{~min}$ & Annegowda et al. (2012) \\
\hline & & DPPH: $77.2 \pm 1.53 \%$ inhibition, FRAP: $2.3 \pm 0.02 \mathrm{Mm} \mathrm{FRF/g} \mathrm{in} 15 \mathrm{~min}$ & \\
\hline & & DPPH: $87.4 \pm 0.41 \%$ inhibition, FRAP: $2.4 \pm 0.00 \mathrm{Mm}$ FRF/g in $30 \mathrm{~min}$ & \\
\hline & & DPPH: $83.3 \pm 0.59 \%$ inhibition, FRAP: $2.3 \pm 0.01 \mathrm{Mm}$ FRF/g in $45 \mathrm{~min}$ & \\
\hline & & DPPH: $79.1 \pm 1.14 \%$ inhibition, FRAP: $2.2 \pm 0.05 \mathrm{Mm} \mathrm{FRF/g} \mathrm{in} 60 \mathrm{~min}$ & \\
\hline $1: 4(\mathrm{w} / \mathrm{v})$ & NR & DPPH: $500.00 \mathrm{mg} \mathrm{TE} / 100 \mathrm{~g} \mathrm{FW}$ & Murillo et al. (2012) \\
\hline $1: 3(\mathrm{w} / \mathrm{v})$ & NR & DPPH: $1.31 \pm 0.53 \mathrm{IC}_{50} \mathrm{mg} / \mathrm{mL}$, FRAP: $19.78 \pm 10.44 \mu \mathrm{mol} \mathrm{TE} / \mathrm{g} F W$ & Zainudin et al. (2012) \\
\hline $1: 10(\mathrm{w} / \mathrm{v})$ & NR & DPPH: $73.48 \pm 4.53 \mathrm{IC}_{50} \mathrm{mg} / \mathrm{mL}$ & Batiston et al. (2013) \\
\hline \multirow[t]{2}{*}{$1: 10(\mathrm{w} / \mathrm{v})$} & $80 \%$ & DPPH: $22.82 \pm 2.21 \%$ inhibition, FRAP: $0.16 \pm 0.02 \mathrm{mM} \mathrm{FeSO} 4 / 100 \mathrm{~g} F W$ in UF & Lim \& Lee (2013) \\
\hline & & DPPH: $38.85 \pm 6.63 \%$ inhibition, FRAP: $0.52 \pm 0.04 \mathrm{mM}$ FeSO4/100 g FW in MF & \\
\hline $1: 10(\mathrm{w} / \mathrm{v})$ & $100 \%$ & DPPH: $0.625 \mathrm{IC}_{50} \mathrm{mg} / \mathrm{mL}$ & Zainudin et al. (2014) \\
\hline $1: 3(\mathrm{w} / \mathrm{v})$ & $80 \%$ & DPPH: $0.6 \mathrm{IC}_{50} \mathrm{mg} / \mathrm{mL}$ and $91.77 \pm 8.68 \mathrm{mg} \mathrm{VCEAC} / 100 \mathrm{~g} \mathrm{FW}$ & Adiyaman et al. (2016) \\
\hline NR & $70 \%$ & DPPH: $75.00 \%$ inhibition & Rahman et al. (2016) \\
\hline $01: 25$ & $80 \%$ & $\beta$-carotene bleaching: $63 \pm 8$ AOX (\%) & Recuenco \& Lacsamana (2016) \\
\hline \multicolumn{4}{|c|}{ Extraction using acetone } \\
\hline NR & $70 \%$ & FRAP: $9 \pm 0 \mu \mathrm{mol} \mathrm{Fe}(\mathrm{II}) / \mathrm{g} \mathrm{FW}, \mathrm{TEAC}: 11 \pm 2 \mu \mathrm{mol} \mathrm{TE} / \mathrm{g}$ & Luximon-Ramma et al. (2003) \\
\hline NR & $50 \%$ & $\begin{array}{l}\text { ABTS: } 3490 \pm 310 \mathrm{mg} \text { VCEAC/100 } \mathrm{g} \text { and } 5270 \pm 46 \mathrm{mg} \text { TEAC/ } 100 \mathrm{~g} \text { on a } \\
\text { dry basis, FRAP: } 510.3 \pm 68.1 \mu \mathrm{mol} / \mathrm{g} \text { on a dry basis, DPPH: } 3412 \pm 290 \mathrm{mg} \\
\text { VCEAC/100 g and } 5152 \pm 706 \mathrm{mg} \text { TEAC/100 g on a dry basis }\end{array}$ & Shui \& Leong (2006) \\
\hline
\end{tabular}

ABTS: 2,2'-azino-bis (3-ethylbenzothiazoline-6-sulphonic acid); AOX: antioxidant activity; DPPH: 1,1-diphenyl-2-picrylhydrazyl assay; FeSO4: iron (II) sulfate; FJ: fresh juice; FRAP: ferric reducing antioxidant power assay; FRF: ferric reduction to ferrous; FW: fresh weight; GAE: Gallic acid equivalent; MF: mature fruit; MPJ: Microwave-pasteurized juice; NO: nitric oxide; NR: not reported; ORAC: oxygen radical absorbance capacity assay; PJ: pasteurized juice; PSC: Peroxyl radical scavenging capacity; SFJ: sonicated fruit juice; TE: trolox equivalent; TEAC: trolox equivalent antioxidant capacity; UF: unripe fruit; VCEAC: Vitamin C equivalent antioxidant capacity. Results presented as reported by the authors. 
Table 5. Continued...

\begin{tabular}{|c|c|c|c|}
\hline Solid-solvent ratio & $\%$ Solvent & Antioxidant capacity & Reference \\
\hline \multirow[t]{2}{*}{$5: 16(w / v)$} & \multirow[t]{2}{*}{$80 \%$} & $\begin{array}{l}\text { ORAC: } 49.84 \pm 3.44 \mu \mathrm{mol} \text { TE g FW in Taiguo cultivars, the highest values } \\
\text { compared to other cultivars determined by extraction of free phenols. }\end{array}$ & \multirow[t]{2}{*}{ Pang et al. (2016) } \\
\hline & & $\begin{array}{l}\text { PSC: } 457.6 \pm 66.4 \mu \mathrm{mol} \text { VCEAC per } 100 \mathrm{~g} \mathrm{FW} \text { in Taiguo cultivars, the highest } \\
\text { values compared to other cultivars determined by extraction of free phenols. }\end{array}$ & \\
\hline \multicolumn{4}{|c|}{ Extraction using diethyl ether } \\
\hline \multirow[t]{5}{*}{ NR } & \multirow[t]{5}{*}{ NR } & ABTS: $1.02 \mathrm{E}+01 \pm 3.465 \mathrm{Mmol} \mathrm{TE} / \mathrm{L}$ of sample cultivated in Granada, Spain & \multirow[t]{5}{*}{ Esteban Muñoz et al. (2018) } \\
\hline & & ABTS: $7.18 \mathrm{E}+00 \pm 4.952 \mathrm{Mmol} \mathrm{TE} / \mathrm{L}$ of sample cultivated in Malaga, Spain & \\
\hline & & DPPH: $1.56 \mathrm{E}+01 \pm 4.273 \mathrm{Mmol}$ TE/L of sample cultivated in Malaga, Spain & \\
\hline & & FRAP: $7.78 \mathrm{E}+00 \pm 1.854 \mathrm{Mmol} \mathrm{TE} / \mathrm{L}$ of sample cultivated in Granada, Spain & \\
\hline & & FRAP: $6.14 \mathrm{E}+00 \pm 2.755 \mathrm{Mmol} \mathrm{TE} / \mathrm{L}$ of sample cultivated in Malaga, Spain & \\
\hline \multicolumn{4}{|c|}{ Solvent free } \\
\hline & & DPPH: $97.11 \%$ inhibition, FRAP: $1221.76 \%$ inhibition in FJ & Saikia et al. (2016) \\
\hline & & $\begin{array}{c}\text { DPPH: } 164.87 \pm 8.37 \text { and } 178.89 \pm 5.43 \mathrm{IC}_{50 \mathrm{I}} \text { in fresh samples of Arkin and } \\
\text { Honey sweet cultivars, respectively }\end{array}$ & \multirow[t]{4}{*}{ Ruvini et al. (2017) } \\
\hline & & $\begin{array}{c}\text { DPPH: } 179.27 \pm 4.58 \text { and } 196.62 \pm 4.80 \mathrm{IC}_{50} \text { in dehydrated samples of Arkin } \\
\text { and Honey sweet cultivars, respectively }\end{array}$ & \\
\hline & & $\begin{array}{c}\text { DPPH: } 210.77 \pm 5.87 \text { and } 312.27 \pm 3.88 \mathrm{IC}_{50} \text { in oven-dried drying samples of } \\
\text { Arkin and Honey sweet cultivars, respectively }\end{array}$ & \\
\hline & & $\begin{array}{c}\text { DPPH: } 395.26 \pm 17.25 \text { and } 483.93 \pm 9.43 \mathrm{IC}_{50} \text { in sun-dried samples of Arkin } \\
\text { and Honey sweet cultivars, respectively }\end{array}$ & \\
\hline & & ABTS: $18.1 \pm 0.51 \mathrm{Mmol}$ TE/g DM, FRAP: $4.61 \pm 0.70 \mathrm{Mmol} \mathrm{TE} / \mathrm{g}$ DM & Otero et al. (2020) \\
\hline & & $\begin{array}{c}\text { ABTS: } 722.71 \pm 12.25 \mu \mathrm{g} \mathrm{GAE} / \mathrm{g} \text { extract, NO: } 190 \mu \mathrm{mol} / \mathrm{L} \text { extract and } \\
27.48 \pm 1.8 \mathrm{IC}_{50} \mu \mathrm{g} \text { extract }\end{array}$ & Pothasak et al. (2020) \\
\hline
\end{tabular}

ABTS: 2,2'-azino-bis (3-ethylbenzothiazoline-6-sulphonic acid); AOX: antioxidant activity; DPPH: 1,1-diphenyl-2-picrylhydrazyl assay; FeSO4: iron (II) sulfate; FJ: fresh juice; FRAP: ferric reducing antioxidant power assay; FRF: ferric reduction to ferrous; FW: fresh weight; GAE: Gallic acid equivalent; MF: mature fruit; MPJ: Microwave-pasteurized juice; NO: nitric oxide; NR: not reported; ORAC: oxygen radical absorbance capacity assay; PJ: pasteurized juice; PSC: Peroxyl radical scavenging capacity; SFJ: sonicated fruit juice; TE: trolox equivalent; TEAC: trolox equivalent antioxidant capacity; UF: unripe fruit; VCEAC: Vitamin C equivalent antioxidant capacity. Results presented as reported by the authors.

value of antioxidant capacity in the tart-type fruit in a mature state (stage 4) by means of the DPPH and FRAP technique. They reported $74 \%$ inhibition values and 5,1023 Mmol/trolox equivalent (TE), in DPPH and FRAP assays, respectively. Using the $\beta$-Carotene bleaching activity technique, they obtained a value of $94.28 \pm 1.42 \%$ antioxidant activity (AOX). Chauhan $\&$ Kapfo (2016) analyzed the antioxidant capacity in fresh and dry matter using the DPPH and trolox equivalent antioxidant capacity (TEAC) techniques. They reported a higher antioxidant capacity in fresh matter by DPPH with $100 \pm 6.2 \mathrm{IC}_{50} \mu \mathrm{g} / \mathrm{mL}$, and a lower antioxidant capacity using the TEAC technique with $0.37 \pm 0.023$. In contrast, they obtained a lower value of antioxidant capacity in dry matter by DPPH with $150 \pm 3.4 \mathrm{IC}_{50}$ $\mu \mathrm{g} / \mathrm{mL}$ and a higher value by means of the TEAC technique with $1.05 \pm 0.005$. The authors attribute the antioxidant capacity to the compounds found in this study--protocatechuic acid trimer in dry matter and the synaptic acid in fresh and dry matter.

In ethanolic extracts, Leong \& Shui (2002) reported $278 \pm 22.3 \mathrm{mg}$ VCEAC/100 g per ABTS, similar to what was reported in Psidium guajava with $270 \pm 18.8 \mathrm{mg}$ AEAC/100 g by ABTS in the same study. The result obtained from the fruit of
A. carambola L. falls within the range reported by Shui \& Leong (2004) in aqueous extract. Muñoz-Jáuregui et al. (2007) reported antioxidant capacity values of $403.31 \mathrm{EC}_{50} \mathrm{mg} / \mathrm{mL}$ by $\mathrm{DPPH}$, and $0.80 \mu \mathrm{mol} / \mathrm{g}$ by TEAC. In another study, Ruvini et al. (2017) obtained greater antioxidant capacity using a dehydrator for samples from both cultivars (Arkin and Honey sweet) reporting values of $179.27 \pm 4.58$ and $196.62 \pm 4.80 \mathrm{IC}_{50}$, respectively, by DPPH. The lowest antioxidant capacity was reported in samples treated by the sun-drying process, with $395.26 \pm 17.25$ and $483.93 \pm 9.43 \mathrm{IC}_{50}$ in the Arkin and Honey sweet cultivars, respectively. Lim et al. (2007) reported concentrations of $3.8 \pm 2.1 \mathrm{IC}_{50} \mathrm{mg} / \mathrm{mL}$ and $98 \pm 55 \mathrm{mg}$ VCEAC/100 g using the DPPH technique--values being similar to those reported for the common guava (Psidium guajava) and papaya (Carica papaya L.) by the same technique, with values of $2.11 \pm 0.63 \mathrm{IC}_{50} \mathrm{mg} / \mathrm{mL}$ and $3.5 \pm 0.9 \mathrm{IC}_{50} \mathrm{mg} / \mathrm{mL}$. These are also tropical fruits common in Malaysia, and their high antioxidant capacity is due, to a certain extent, to their high content of phenolic compounds (Ali et al., 2010). The results obtained in this study were similar to those reported by Yan et al. (2013) using DPPH with values of $1.88 \pm 0.62 \mathrm{IC}_{50} \mathrm{mg} / \mathrm{mL}$; and values of $47.73 \pm 5.54 \%$ AOX by the $\beta$-Carotene bleaching assay, similar to that reported by Abdullah \& Noriham (2014) in an 
aqueous extract. In the studio by Yan et al. (2013) the antioxidant capacity of $A$. carambola $L$. was found to be higher than the variety $A$. bilimbi $L$. with $6.93 \pm 0.25 \mathrm{IC}_{50} \mathrm{mg} / \mathrm{mL}$ by $\mathrm{DPPH}$ and $28.41 \pm 5.31 \%$ by the $\beta$-Carotene bleaching assay. Ali et al. (2010) reported antioxidant capacity values in A. carambola $L$. of $81.03 \pm 1.97 \mathrm{mg}$ TE/100 $\mathrm{mg}$ of fruit by DPPH and 78,770 \pm 0.35 TE/100 mg of fruit by FRAP, lower values than were obtained from Psidium guajava, with $176.06 \pm 1.92 \mathrm{TE} / 100 \mathrm{mg}$ of fruit by DPPH, and $139.29 \pm 0.54 \mathrm{TE} / 100 \mathrm{mg}$ of fruit by FRAP, in the same study. Guevara et al. (2019) reported antioxidant capacity values in A. carambola L. of $1215.34 \pm 101.98 \mu \mathrm{mol} \mathrm{TE} / \mathrm{g}$ FW by DPPH and values of $3370.94 \pm 308.02 \mu \mathrm{mol} \mathrm{TE} / \mathrm{g}$ FW by FRAP.

In methanolic extracts, Bhat et al. (2011) reported a small increase in antioxidant capacity with inhibition percentage values from $85.74 \pm 0.36 \%$ to $88.08 \pm 0.77 \%$ inhibition by means of $\mathrm{DPPH}$, after exposing the sample to UV light from 0 to $60 \mathrm{~min}$, respectively. Similar results were reported by Shofian et al. (2011) by the DPPH technique with results of $87 \%$ and $95 \%$ inhibition in lyophilized and fresh samples, respectively. This difference in results was probably due to a series of changes in the chemical structures when cold-drying, causing oxidation of certain compounds (Marques et al., 2006). Rahman et al. (2016) reported $75.00 \%$ inhibition by DPPH, a slightly different from what was reported by Shofian et al. (2011), but consistent with the findings of Annegowda et al. (Annegowda et al., 2012) in methanolic extract. Lim \& Lee (2013) analyzed antioxidant capacity in immature and mature samples, and find it greater in mature samples, with values of $38.85 \pm 6.63 \%$ inhibition by $\mathrm{DPPH}$ and $0.52 \pm 0.04 \mathrm{mM} \mathrm{FeSO} 4 / 100 \mathrm{~g}$ FW by FRAP. Batiston et al. (2013) reported antioxidant capacity values in A. carambola L. of $73.48 \pm 4.53 \mathrm{IC}_{50} \mathrm{mg} / \mathrm{mL}$ per DPPH. These values were higher than those obtained in Psidium guajava L. with values of $118.22 \pm 3.89 \mathrm{IC}_{50} \mathrm{mg} / \mathrm{mL}$ per DPPH, reported in the same study. However, Zainudin et al. (2012) obtained higher antioxidant capacity analyzed by DPPH, with values of $1.31 \pm 0.53 \mathrm{IC}_{50} \mathrm{mg} /$ $\mathrm{mL}$ and $19.78 \pm 10.44 \mu \mathrm{mol} \mathrm{TE} / \mathrm{g}$ FW by FRAP. These results were similar to those reported by Yan et al. (2013) but from ethanolic extract. Adiyaman et al. (2016) reported high antioxidant capacity by $\mathrm{DPPH}$ in $A$. carambola $L$. with values of $0.6 \mathrm{IC}_{50} \mathrm{mg} / \mathrm{mL}$, a result that agrees with that reported by Zainudin et al. (2014) with $0.625 \mathrm{IC}_{50} \mathrm{mg} \mathrm{mL}$. Murillo et al. (2012) studied the antioxidant capacity of some fruits of Panama, including A. carambola L., determining values of $500.00 \mathrm{mg} \mathrm{TE} / 100 \mathrm{~g} \mathrm{FW}$ by DPPH. In this study, however, the results were lower than those reported in Psidium guajava L., values of $780.00 \mathrm{TE} / 100 \mathrm{~g} \mathrm{FW}$ in the same study. Mahattanatawee et al. (2006) reported antioxidant capacity values by DPPH of $620.2 \pm 40.9 \mu \mathrm{g}$ GAE/g of puree and by oxygen radical absorbance capacity assay (ORAC) values of $12.9 \pm 1.0 \mu \mathrm{g} \mathrm{TE} / \mathrm{g}$ of puree in A. carambola L., reporting lower antioxidant capacity that in the study by Murillo et al. (2012). Recuenco \& Lacsamana (2016) reported a value of $63 \pm 8 \%$ AOX using the $\beta$-carotene bleaching technique, higher than was reported by Yan et al. (2013) in ethanolic extract.

Luximon-Ramma et al. (2003) studied various exotic fruits of Mauritious and find, in extracts of $A$. carambola $L$. prepared using acetone, antioxidant capacity values of $9 \pm 0 \mu \mathrm{mol} \mathrm{Fe}$ (II)/g FW by FRAP and $11 \pm 2 \mu \mathrm{mol} \mathrm{TE} / \mathrm{g}$ by TEAC. This was higher than was found in fruits such as Psidium guajava
L, orange (Passiflora edulis), and litchi (Litchi chinensis). The antioxidant capacity results in $A$. carambola $L$. reported by Shui \& Leong (2006) range from $3490 \pm 310$ to $5270 \pm 46 \mathrm{mg}$ TEAC/100 g on a dry basis by ABTS; $3412 \pm 290 \mathrm{mg}$ AEAC/100 g and $5152 \pm 706 \mathrm{mg}$ TEAC/100 g on a dry basis by DPPH, and by means of FRAP, the authors reported values of $510.3 \pm 68.1 \mu \mathrm{mol} / \mathrm{g}$ on a dry basis. Pang et al. (2016) reported the antioxidant capacity of the extract of free phenols with values of $49.84 \pm 3.44 \mu \mathrm{mol}$ TE $\mathrm{g}$ FW by the ORAC method in the cultivar of Taiguo, 1.4 times greater than the Xiangmi cultivar, and 1.51 and 2.1 times greater than the Hong and Honglong cultivars, respectively. The Taiguo cultivar yielded the highest amount, $457.6 \pm 66.4 \mu \mathrm{mol}$ VCEAC per $100 \mathrm{~g} \mathrm{FW}$, using the peroxyl radical scavenging capacity (PSC) technique, $42.02 \%$ higher than for the Xiangmi cultivar, and $42.36 \%$ and $61.21 \%$ higher than the Hong and Honglong cultivars, respectively. In these results; as previously mentioned, different factors influenced the maturity of the fruit and the environmental conditions of each cultivar (Ben Ghorbal et al., 2018). Esteban Muñoz et al. (2018) used diethyl ether to make extracts and compare the antioxidant capacity of the A. carambola L. fruit cultivated in Granada, Spain and in Malaga, Spain. Through the ABTS method they reported values of $10.2 \pm 3.465 \mathrm{Mmol} \mathrm{TE} / \mathrm{L}$ in the Granada sample and $7.18 \pm 4,952 \mathrm{Mmol} \mathrm{TE} / \mathrm{L}$ in the Malaga sample. By means of $\mathrm{DPPH}$ they obtained values of $14.8 \pm 4.732 \mathrm{Mmol} \mathrm{TE} / \mathrm{L}$ from the Granada sample and $15.6 \pm 4.273 \mathrm{Mmol}$ TE/L from the Malaga sample, and finally by the FRAP method they obtained values of $7.78 \pm 1.854 \mathrm{Mmol} \mathrm{TE} / \mathrm{L}$ in the Granada sample and $6.14 \pm 2,755 \mathrm{Mmol} \mathrm{TE} / \mathrm{L}$ in the Malaga sample.

Saikia et al. (2016) reported the antioxidant capacity in fresh sample by different extraction methods without the use of solvent. Values ranged from $85.58 \%$ to $97.11 \%$ inhibition by means of the DPPH technique, not a significant difference. Using the FRAP technique, inhibition values from $680.56 \%$ to $1829.58 \%$ were reported. In general, the microwave extraction method resulted in higher antioxidant capacity, probably because the phenolic compounds found in the vegetable matrix of the juice of $A$. carambola $L$. are released when heated for a short period of time (Lovrić et al., 2017). Otero et al. (2020) obtained antioxidant capacity values of $18.1 \pm 0.51 \mathrm{Mmol} \mathrm{TE} / \mathrm{g} \mathrm{DM}$ by ABTS and values of $4.61 \pm 0.70 \mathrm{Mmol} \mathrm{TE} / \mathrm{g}$ DM by FRAP, results than what was reported by Esteban Muñoz et al. (2018). Pothasak et al. (2020) for their part, reported antioxidant capacity values of $722.71 \pm 12.25 \mu \mathrm{g}$ GAE/g extract by ABTS, and values of $190 \mu \mathrm{mol} / \mathrm{L}$ using the nitric oxide (NO) technique.

\section{Identification of phenolic compounds in fruit $A$. carambola $L$.}

A study by Shui \& Leong (2004) on the identification of phenolic compounds from the fruit of $A$. carambola $L$. in aqueous extracts, reported the presence of (-) epicatechin and proanthocyanidins by means of HPLC-DAD-ESI-MS (Table 6). Chauhan \& Kapfo (2016) reported only the presence of protocatechuic acid trimer and sinapic acid tetramer in aqueous extract using HPLC-ESIMS and FT-IR. Khanam et al. (2015) performed an aqueous extraction of the fruit of $A$. carambola $L$. and analyzed the phenolic compounds using HPLC. They reported different percentages of 
Table 6. Identification of phenolic compounds in the fruit of fruit A. carambola L.

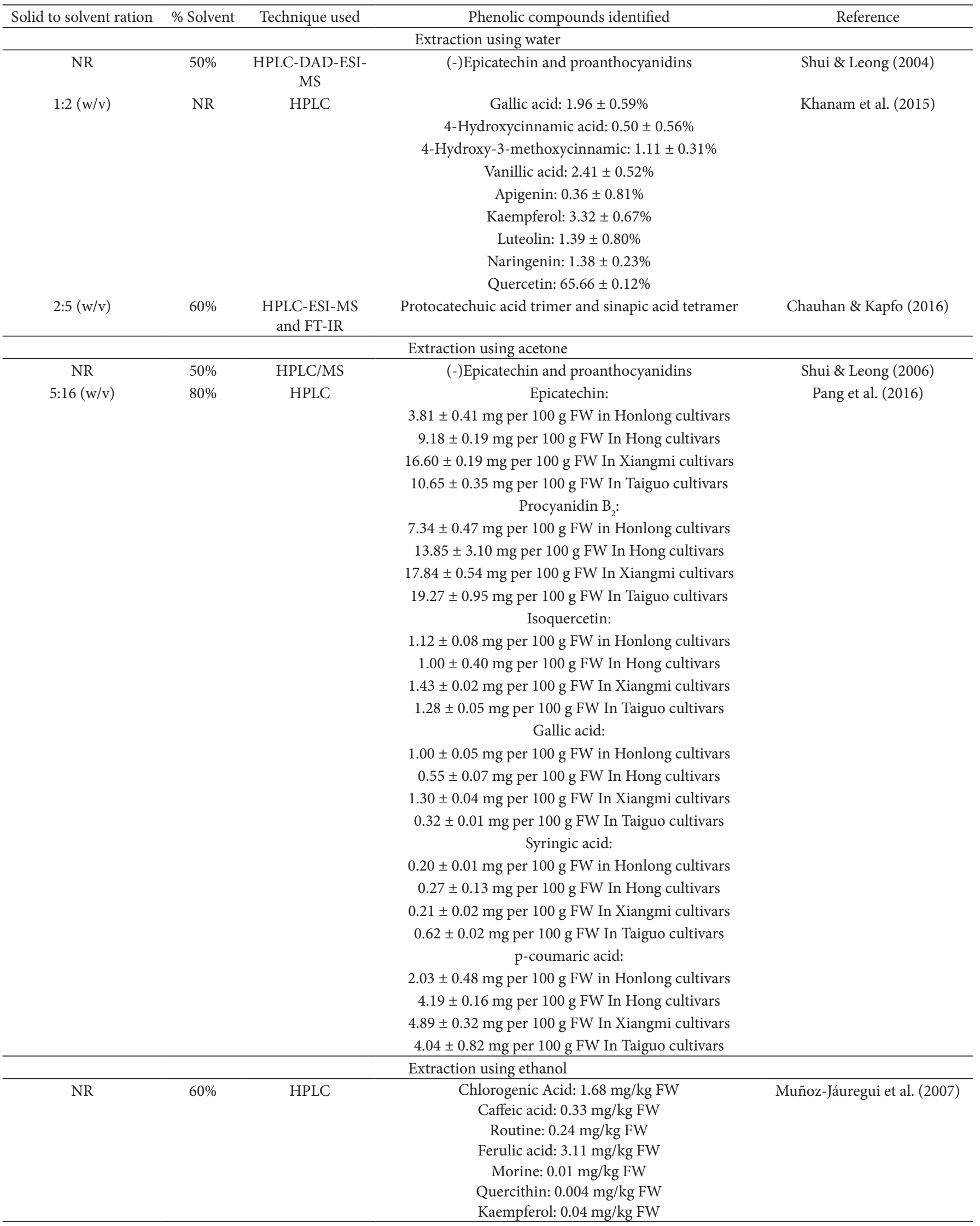

FW: fresh weight; NR: Not reported; FJ: fresh juice; MPJ: Microwave-pasteurized juice; PJ: pasteurized juice; SFJ: sonicated fruit juice. Results presented as reported by the authors. 
Table 6. Continued...

\begin{tabular}{|c|c|c|c|c|}
\hline Solid to solvent ration & $\%$ Solvent & Technique used & Phenolic compounds identified & Reference \\
\hline \multirow{5}{*}{$1: 2(\mathrm{w} / \mathrm{v})$} & & & 4-Hydroxycinnamic acid: $3.59 \pm 0.43 \%$ & \\
\hline & & & Vanillic acid: $4.54 \pm 0.99 \%$ & \\
\hline & & & Kaempferol: $4.25 \pm 0.41 \%$ & \\
\hline & & & Naringenin: $3.43 \pm 0.82 \%$ & \\
\hline & & & Quercetin: $0.37 \pm 0.11 \%$ & \\
\hline \multirow[t]{13}{*}{$1: 10(w / v)$} & $\mathrm{HCl} 1 \mathrm{~N}$ & RP-HPLC & Gallic acid: $41.90 \pm 0.05$ extract $\mathrm{mg} / 100 \mathrm{~g}$ in pomace & Saikia et al. (2015) \\
\hline & & & Catechin: $48.08 \pm 0.02$ extract $\mathrm{mg} / 100 \mathrm{~g}$ in pomace & \\
\hline & & & Caffeic acid: $38.09 \pm 0.02$ extract $\mathrm{mg} / 100 \mathrm{~g}$ in pomace & \\
\hline & & & Rutin: $2.41 \pm 0.02$ extract $\mathrm{mg} / 100 \mathrm{~g}$ in pomace & \\
\hline & & & Quercetin: $3.67 \pm 0.04$ extract $\mathrm{mg} / 100 \mathrm{~g}$ in pomace & \\
\hline & & & Gallic acid: $4.89 \pm 0.04$ extract $\mathrm{mg} / 100 \mathrm{~g}$ in juice & \\
\hline & & & Catechin: $2.90 \pm 0.01$ extract $\mathrm{mg} / 100 \mathrm{~g}$ in juice & \\
\hline & & & Caffeic acid: NR & \\
\hline & & & Chlorogenic acid: $2.17 \pm 0.08$ extract $\mathrm{mg} / 100 \mathrm{~g}$ in juice & \\
\hline & & & Syringic acid: $3.51 \pm 0.04$ extract $\mathrm{mg} / 100 \mathrm{~g}$ in juice & \\
\hline & & & Ferulic acid: $4.21 \pm 0.03$ extract $\mathrm{mg} / 100 \mathrm{~g}$ in juice & \\
\hline & & & Coumaric acid: NR & \\
\hline & & & Rutin: NR & \\
\hline \multirow{7}{*}{ NR } & & & Ellagic acid: $7.43 \mathrm{E}+02 \pm 0.067 \mu \mathrm{g} / 100 \mathrm{~g}$ of fresh fruit & \\
\hline & & & $\begin{array}{l}\text { p-hydroxybenzoic acid: } 1.59 \mathrm{E}+0.3 \pm 0.090 \mu \mathrm{g} / 100 \mathrm{~g} \text { of } \\
\text { fresh fruit }\end{array}$ & \\
\hline & & & Protocatechuic acid: $1.21 \mathrm{E}+02 \pm 0.010 \mu \mathrm{g} / 100 \mathrm{~g}$ of fresh fruit & \\
\hline & & & $\begin{array}{c}\text { 3,5-dimethoxybenzoic acid: } 2.50 \mathrm{E}+02 \pm 0.034 \mu \mathrm{g} / 100 \mathrm{~g} \text { of } \\
\text { fresh fruit }\end{array}$ & \\
\hline & & & Quercetin: $1.52 \mathrm{E}+01 \pm 0.001 \mu \mathrm{g} / 100 \mathrm{~g}$ of fresh fruit & \\
\hline & & & Naringenin: $3.75 \mathrm{E}+00 \pm 0.002 \mu \mathrm{g} / 100 \mathrm{~g}$ of fresh fruit & \\
\hline & & & Extraction usign metanol & \\
\hline $1: 4(\mathrm{w} / \mathrm{v})$ & $100 \%$ & HPLC-PDA-MS & Catechin, proanthocyanidin dimer and trimer conjugates & Mahattanatawee et al. (2006) \\
\hline \multirow[t]{6}{*}{$1: 3(\mathrm{w} / \mathrm{v})$} & $80 \%$ & HPLC & Gallic acid: $3.78 \pm 0.31 \mathrm{mg} / 100 \mathrm{~g} \mathrm{FW}$ & Adiyaman et al. (2016) \\
\hline & & & Ferulic acid: $16.32 \pm 1.56 \mathrm{mg} / 100 \mathrm{~g} \mathrm{FW}$ & \\
\hline & & & Caffeic acid: $5.01 \pm 0.42 \mathrm{mg} / 100 \mathrm{~g} \mathrm{FW}$ & \\
\hline & & & Epi-catechin: $17.42 \pm 1.75 \mathrm{mg} / 100 \mathrm{~g} \mathrm{FW}$ & \\
\hline & & & Catechin: $1.33 \pm 0.04 \mathrm{mg} / 100 \mathrm{~g} \mathrm{FW}$ & \\
\hline & & & Quercetin: $38.01 \pm 2.16 \mathrm{mg} / 100 \mathrm{~g} \mathrm{FW}$ & \\
\hline \multirow[t]{3}{*}{ NR } & NR & HPTLC & Gallic acid: $0.96 \%$ & Verma et al. (2018) \\
\hline & & & Protocatechuic acid: $0.05 \%$ & \\
\hline & & & Quercetin: $0.40 \%$ & \\
\hline
\end{tabular}

FW: fresh weight; NR: Not reported; FJ: fresh juice; MPJ: Microwave-pasteurized juice; PJ: pasteurized juice; SFJ: sonicated fruit juice. Results presented as reported by the authors. 
Table 6. Continued...

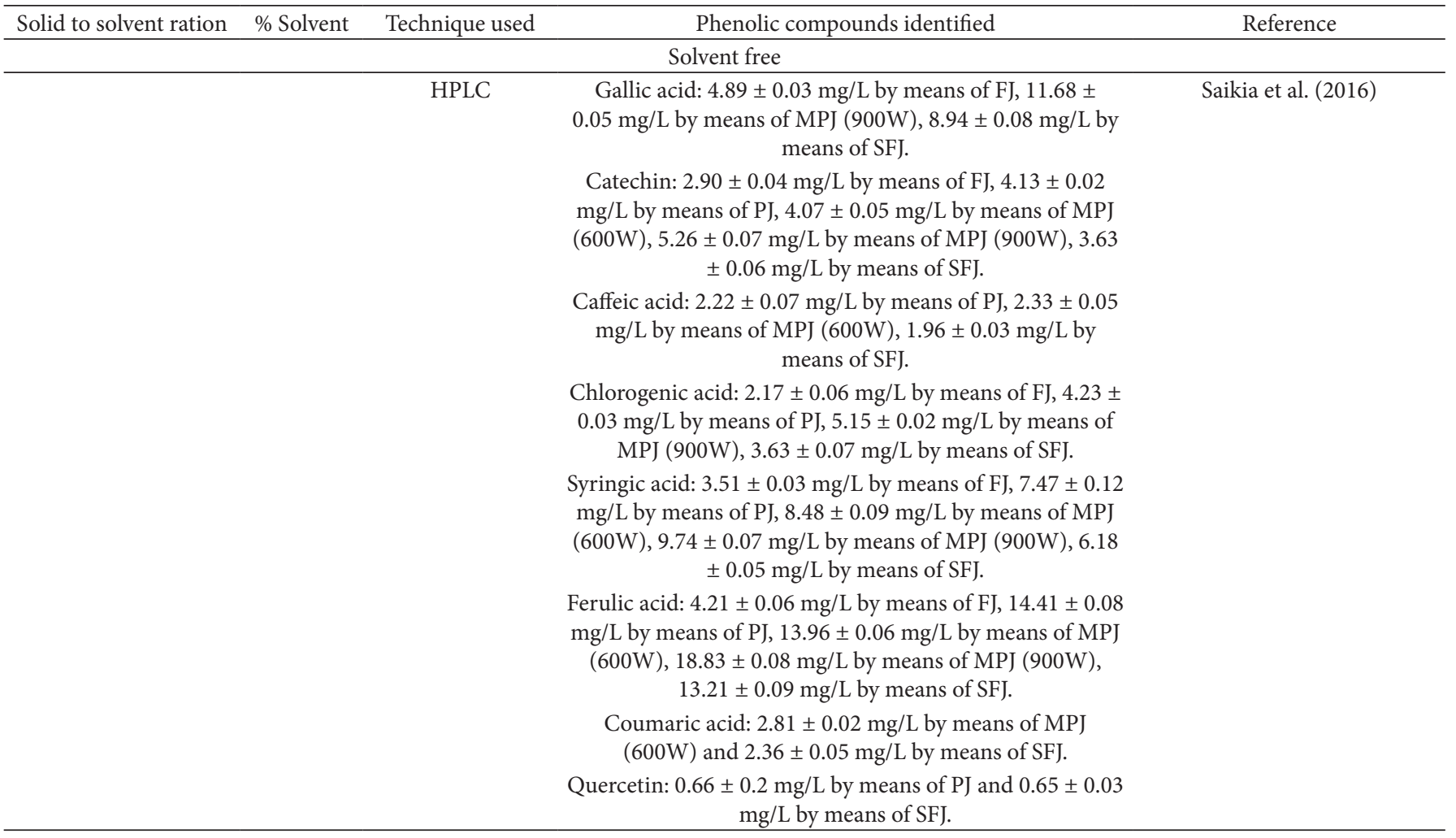

FW: fresh weight; NR: Not reported; FJ: fresh juice; MPJ: Microwave-pasteurized juice; PJ: pasteurized juice; SFJ: sonicated fruit juice. Results presented as reported by the authors.

phenolic compounds: gallic acid $1.96 \pm 0.59 \%$; 4 -hydroxycinnamic acid $0.50 \pm 0.56 \%$; 4-hydroxy-3-methoxycinnamic $1.11 \pm 0.31 \%$; vanillic acid: $2.41 \pm 0.52 \%$; apigenin $0.36 \pm 0.81 \%$; kaempferol $3.32 \pm 0.67 \%$; luteolin $1.39 \pm 0.80 \%$; naringenin $1.38 \pm 0.23 \%$ and quercetin $65.66 \pm 0.12 \%$. Furthermore, these authors analyzed the phenolic profile in ethanolic extract and reported: chlorogenic acid $1.94 \pm 0.25 \%$; gallic acid $6.47 \pm 0.37 \%$; 4 -hydroxycinnamic acid $3.59 \pm 0.43 \%$; 4-hydroxy-3-methoxycinnamic $1.87 \pm 0.54 \%$; vanillic acid $4.54 \pm 0.99 \%$; kaempferol $4.25 \pm 0.41 \%$; luteolina $11.40 \pm 0.39 \%$; myricetin $1.77 \pm 0.43 \%$; naringenin $3.43 \pm 0.82 \%$ and quercetin $0.37 \pm 0.11 \%$. In general, they find greater amounts of phenolic compounds in the ethanolic extract than in the aqueous extract. On the other hand, Muñoz-Jáuregui et al. (2007) determined the HPLC concentration of different phenolic compounds in ethanolic extract and report: chlorogenic acid $1.68 \mathrm{mg} / \mathrm{kg} \mathrm{FW}$; caffeic acid $0.33 \mathrm{mg} / \mathrm{kg} \mathrm{FW}$; rutin $0.24 \mathrm{mg} / \mathrm{kg} \mathrm{FW}$; ferulic acid $3.11 \mathrm{mg} / \mathrm{kg} \mathrm{FW}$; morin $0.01 \mathrm{mg} / \mathrm{kg} \mathrm{FW}$; quercitin $0.004 \mathrm{mg} / \mathrm{kg}$ FW and kaemferol $0.04 \mathrm{mg} / \mathrm{kg}$ FW. Saikia et al. (2015) used RP-HPLC to determine the concentration of different phenolic compounds from ethanolic extracts of the pomace and fruit juice. The authors reported: gallic acid $41.90 \pm 0.05$ extract $\mathrm{mg} / 100 \mathrm{~g}$ in pomace; catechin $48.08 \pm 0.02$ extract $\mathrm{mg} / 100 \mathrm{~g}$ in pomace; caffeic acid $38.09 \pm 0.02$ extract $\mathrm{mg} / 100 \mathrm{~g}$ in pomace; chlorogenic acid $22.01 \pm 0.05$ extract $\mathrm{mg} / 100 \mathrm{~g}$ in pomace; syringic acid $13.10 \pm 0.09$ extract $\mathrm{mg} / 100 \mathrm{~g}$ in pomace; ferulic acid $21.30 \pm 0.11$ extract $\mathrm{mg} / 100 \mathrm{~g}$ in pomace; coumaric acid $21.45 \pm 0.03$ extract $\mathrm{mg} / 100 \mathrm{~g}$ in pomace; rutin $2.41 \pm 0.02$ extract $\mathrm{mg} / 100 \mathrm{~g}$ in pomace; quercetin $3.67 \pm 0.04$ extract $\mathrm{mg} / 100 \mathrm{~g}$ in pomace; gallic acid
$4.89 \pm 0.04$ extract $\mathrm{mg} / 100 \mathrm{~g}$ in juice; catechin: $2.90 \pm 0.01$ extract $\mathrm{mg} / 100 \mathrm{~g}$ in juice; chlorogenic acid $2.17 \pm 0.08$ extract $\mathrm{mg} / 100 \mathrm{~g}$ in juice; syringic acid $3.51 \pm 0.04$ extract $\mathrm{mg} / 100 \mathrm{~g}$ in juice and ferulic acid $4.21 \pm 0.03$ extract $\mathrm{mg} / 100 \mathrm{~g}$ in juice. In the extract of the pomace of $A$. carambola $L$. other phenolic compounds different from those reported in the juice were identified. Furthermore, the concentrations of phenolic compounds were higher in this extract than in the juice of A. carambola L. Shui \& Leong (2006) reported the presence of (-) epicatechin, a compound that is one of the main components of proanthocyanidins in fruit, in an extract prepared with acetone and evaluated by HPLC/MS.

Pang et al. (2016) found the Xiangmi cultivar to have the highest amount of epicatechin $(16.60 \pm 0.19 \mathrm{mg}$ per $100 \mathrm{~g} \mathrm{FW})$, procyanidin $\mathrm{B}_{2}(7.84 \pm 0.54 \mathrm{mg}$ per $100 \mathrm{~g} \mathrm{FW})$, isoquercetin $(1.43 \pm 0.02 \mathrm{mg}$ per $100 \mathrm{~g} \mathrm{FW})$, gallic acid $(1.30 \pm 0.04 \mathrm{mg}$ per $100 \mathrm{~g} \mathrm{FW})$, and $p$-coumaric acid $(4.89 \pm 0.32 \mathrm{mg}$ per $100 \mathrm{~g}$ FW). The Taiguo cultivar was found only be higher in syringic acid $(0.62 \pm 0.02 \mathrm{mg}$ per $100 \mathrm{~g} \mathrm{FW})$, however, in this cultivar the authors also obtained high concentrations of epicatechin, procyanidin $\mathrm{B}_{2}$, isoquercetin, and $p$-coumaric acid compared to the other cultivars. No other compounds were reported such as caffeic acid, chlorogenic acid, ferulic acid, rutin, or quercetin as reported by Saikia et al. (2015) in ethanolic extract, but this probably due to the type of solvent and extraction process used.

Esteban Muñoz et al. (2018) analyzed the phenolic profile of $A$. carambola L. from an extract made with diethyl ether, using UPLCESI-MS/MS. They reported, in proportion to fresh fruit: caffeic acid 
$137 \pm 0.011 \mu \mathrm{g} / 100 \mathrm{~g}$; ferulic acid $284 \pm 0.022 \mu \mathrm{g} / 100 \mathrm{~g}$; -cumaric acid $400 \pm 0.020 \mu \mathrm{g} / 100 \mathrm{~g}$; gallic acid $4,750 \pm 0.230 \mu \mathrm{g} / 100 \mathrm{~g}$; vanillic acid $168 \pm 0.002 \mu \mathrm{g} / 100 \mathrm{~g}$ o; ellagic acid $743 \pm 0.067 \mu \mathrm{g} / 100 \mathrm{~g}$; p-hydroxybenzoic acid 1,590 $\pm 0.090 \mu \mathrm{g} / 100 \mathrm{~g} \mathrm{o}$; protocatechuic acid $121 \pm 0.010 \mu \mathrm{g} / 100 \mathrm{~g}$; 3,5-dimethoxybenzoic acid $250 \pm 0.034 \mu \mathrm{g} / 100 \mathrm{~g}$; quercetin $15.2 \pm 0.001 \mu \mathrm{g} / 100 \mathrm{~g}$; and naringenin $3.75 \pm 0.002 \mu \mathrm{g} / 100 \mathrm{~g}$. Mahattanatawee et al. (2006) used HPLC-PDA-MS to report the presence of catechin, proanthocyanidin dimer and trimer conjugates in a methanolic extract. Adiyaman et al. (2016) determined the concentration and identification of the following compounds using HPLC in a methanolic extract: gallic acid $3.78 \pm 0.31 \mathrm{mg} / 100 \mathrm{~g} \mathrm{FW}$; ferulic acid $16.32 \pm 1.56 \mathrm{mg} / 100 \mathrm{~g}$ FW; caffeic acid $5.01 \pm 0.42 \mathrm{mg} / 100 \mathrm{~g}$ FW; epi-catechin $17.42 \pm 1.75 \mathrm{mg} / 100 \mathrm{~g} \mathrm{FW}$; catechin $1.33 \pm 0.04 \mathrm{mg} / 100 \mathrm{~g}$ FW; quercetin $38.01 \pm 2.16 \mathrm{mg} / 100 \mathrm{~g}$ FW. Verma et al. (2018) analyzed a methanolic extract and using HPTLC reported gallic acid $0.96 \%$; protocatechuic acid $0.05 \%$; and quercetin $0.40 \%$. Saikia et al. (2016) analyzed phenolic profiles obtained by different extraction methods (previously mentioned). The phenolic compounds identified and quantified were: gallic acid between $4.89 \pm 0.03 \mathrm{mg} / \mathrm{L}$ and $11.68 \pm 0.05 \mathrm{mg} / \mathrm{L}$; catechin from $2.90 \pm 0.04 \mathrm{mg} / \mathrm{L}$ to $5.26 \pm 0.07 \mathrm{mg} / \mathrm{L} ;$ caffeic acid $1.96 \pm 0.03 \mathrm{mg} / \mathrm{L}$ to $2.33 \pm 0.05 \mathrm{mg} / \mathrm{L}$; chlorogenic acid $2.17 \pm 0.06 \mathrm{mg} / \mathrm{L}$ to $5.15 \pm$ $0.02 \mathrm{mg} / \mathrm{L}$; syringic acid $3.51 \pm 0.03 \mathrm{mg} / \mathrm{L}$ to $9.74 \pm 0.07 \mathrm{mg} / \mathrm{L}$; ferulic acid $4.21 \pm 0.06 \mathrm{mg} / \mathrm{L}$ to $18.83 \pm 0.08 \mathrm{mg} / \mathrm{L}$; coumaric acid $2.36 \pm 0.05 \mathrm{mg} / \mathrm{L}$ to $2.81 \pm 0.02 \mathrm{mg} / \mathrm{L}$ and quercetin 0.66 $\pm 0.2 \mathrm{mg} / \mathrm{L}$ to $0.65 \pm 0.03 \mathrm{mg} / \mathrm{L}$, by HPLC. In this study, the different extraction processes resulted in a higher concentration of compounds, as well as the detection of other phenolic compounds in addition to those found in fresh fruit juice. In some cases, however, the phenolic compounds were oxidized. This is due to the thermolability in some compounds under temperatures used in each of the extraction methods. The detection of other compounds is also influenced by the extraction method, which causes the separation of the compounds of interest from the plant matrix, or which are bound to other components such as proteins, lipids and carbohydrates (Kopjar et al., 2014).

\section{Conclusion}

The phenolic compounds reported in the fruit of $A$. carambola $L$. are: (-) epicatechin, proanthocyanidins, gallic acid, 4-hydroxycinnamic acid, 4-hydroxy-3-methoxycinnamic, 3,5-dimethoxybenzoic acid, apigenin, kaempferol, luteolin, naringenin, morine, quercetin, myricetin, catechin, vanillic acid, caffeic acid, chlorogenic acid, $p$-cumaric acid, ellagic acid, protocatechuic acid, p-hydroxybenzoic acid, syringic acid, ferulic acid, rutin, protocatechuic acid trimer and sinapic acid tetramer, reported in aqueous extracts, alcoholic extracts, and extracts prepared with diethyl ether and in fruit juice. However, the phenolic profile varies in most of the studies surveyed, due to various factors that involve geolocation, agro-climatic conditions, sample maturation, post-harvest treatment, as well as the various extraction methodologies and the use and mixtures of different solvents. These variables differ in each of the studies conducted to determine phenolic compounds and antioxidant capacity. In general, however, it can be said that the fruit of A. carambola L. contains high concentrations of TPC and TFC compared to other edible tropical fruits, and is thus a fruit with a high antioxidant capacity.

\section{Acknowledgements}

The review was supported by the Fund for Strengthening Research at the Autonomous University of Queretaro under Grant [Number FOFI-UAQ: FNN-2018-08]. Special thanks to the National Council of Science and Technology of Mexico (CONACYT) for the support of A. V.-M.

\section{References}

Abdullah, A. N., \& Noriham, A. (2014). Antioxidant activity and bioactive components of oxalidaceae fruit extracts. The Malaysian Journal of Analytical Sciences, 18(1), 116-126.

Adiyaman, P., Kanchana, S., Usharani, T., Ilaiyaraja, N., Kalaiselvan, A., \& Kumar, K. R. A. (2016). Identification and quantification of polyphenolic compounds in underutilized fruits (Star fruit and Egg fruit) using HPLC. Indian Journal of Traditional Knowledge, 15(3), 487-493.

Ali, M. A., Devi, L. I., Nayan, V., Chanu, K. V., \& Ralte, L. (2010). Antioxidant activity of fruits available in Aizawl market of Mizoram, India. International Journal of Biological \& Pharmaceutical Research, $1(2), 76-81$.

Annegowda, H. V., Bhat, R., Min-tze, L., Karim, A. A., \& Mansor, S. M. (2012). Influence of sonication treatments and extraction solvents on the phenolics and antioxidants in star fruits. Journal of Food Science and Technology, 49(4), 510-514. http://dx.doi.org/10.1007/ s13197-011-0435-8. PMid:23904662.

Batiston, W. P., Maruyama, S. A., Gomes, S. T. M., Visentainer, J. V., Souza, N. E., \& Matsushita, M. (2013). Total phenolic content and antioxidant capacity of methanolic extracts of ten fruits. Acta Scientiarum. Technology, 35(3), 581-585. http://dx.doi.org/10.4025/ actascitechnol.v35i3.18533.

Ben Ghorbal, A., Leventdurur, S., Agirman, B., Boyaci-Gunduz, C. P., Kelebek, H., Carsanba, E., Darici, M., \& Erten, H. (2018). Influence of geographic origin on agronomic traits and phenolic content of cv. Gemlik olive fruits. Journal of Food Composition and Analysis, 74, 1-9. http://dx.doi.org/10.1016/j.jfca.2018.08.004.

Bhat, R., Ameran, S. B., Voon, H. C., Karim, A. A., \& Tze, L. M. (2011). Quality attributes of starfruit (Averrhoa carambola L. ) juice treated with ultraviolet radiation. Food Chemistry, 127(2), 641-644. http:// dx.doi.org/10.1016/j.foodchem.2011.01.042. PMid:23140712.

Chauhan, J. B., \& Kapfo, W. (2013). Effect of traditional sun-drying on phenolic antioxidants of Averrhoa bilimbi L. International Journal of Applied Biology and Pharmaceutical Technology, 4(2), 26-34.

Chauhan, J. B., \& Kapfo, W. (2016). Effect of traditional sun drying on indigenous star fruit (Averrhoa carambola) from India. International Journal of Plant, Animal and Environmental Sciences, 6(1), 121-133.

Dasgupta, P., Chakraborty, P., \& Bala, N. N. (2013). Averrhoa carambola an updated review. International Journal of Pharma Research \& Review, 2(7), 54-63. Retrieved from http://www.rroij.com/openaccess/averrhoa-carambola-an-updated-review.pdf

Deena, M. J., Athira, A. V., Ayisha, E. V., Gloria, J., Greeshma, P. T., \& Manju, M. B. (2017). Total polyphenols and phytochemical constituents in a few neglected and underutilized tropical minor fruits. Journal of Advances in Biological Science, 4(2), 55-57.

Dembitsky, V. M., Poovarodom, S., Leontowicz, H., Leontowicz, M., Vearasilp, S., Trakhtenberg, S., \& Gorinstein, S. (2011). The multiple 
nutrition properties of some exotic fruits: biological activity and active metabolites. Food Research International, 44(7), 1671-1701. http://dx.doi.org/10.1016/j.foodres.2011.03.003.

Dionísio, A. P., Carvalho-Silva, L. B., Vieira, N. M., Wurlitzer, N. J., Pereira, A. C. S., Borges, M. F., Garruti, D. S., \& Araújo, I. S. (2020a). Antioxidant and prebiotic effects of a beverage composed by tropical fruits and yacon in alloxan-induced diabetic rats. Food Science and Technology, 40(1), 202-208. http://dx.doi.org/10.1590/fst.34518.

Dionísio, A. P., Silva, M. F. G., Carioca, A. A. F., Adriano, L. S., Abreu, F. A. P., Wurlitzer, N. J., Pinto, C. O., \& Pontes, D. F. (2020b). Effect of yacon syrup on blood lipid, glucose and metabolic endotoxemia in healthy subjects: a randomized, double-blind, placebo-controlled pilot trial. Food Science and Technology, 40(1), 194-201. http://dx.doi. org/10.1590/fst.38218.

Esteban Muñoz, A., Barea Álvarez, M., Oliveras-López, M.-J., Giménez Martínez, R., Henares, J. Á. R., \& Olalla Herrera, M. (2018). Determination of polyphenolic compounds by ultra-performance liquid chromatography coupled to tandem mass spectrometry and antioxidant capacity of spanish subtropical Fruits. Agricultural Sciences, 9(2), 180-199. http://dx.doi.org/10.4236/as.2018.92014.

Gaidhani, K. A., Harwalkar, M., Bhambere, D., \& Nirgude, P. S. (2016). Lyophilization/freeze drying:a review. World Journal of Pharmaceutical Research, 4(8), 516-543.

Gao, Y., Ma, S., Wang, M., \& Feng, X. Y. (2017). Characterization of free, conjugated, and bound phenolic acids in seven commonly consumed vegetables. Molecules, 22(11), 1878. http://dx.doi.org/10.3390/ molecules22111878. PMid:29104269.

Granato, D., Barba, F. J., Bursać Kovačević, D., Lorenzo, J. M., Cruz, A. G., \& Putnik, P. (2020). Functional foods: product development, technological trends, efficacy testing, and safety. Annual Review of Food Science and Technology, 11(1), 93-118. http://dx.doi.org/10.1146/ annurev-food-032519-051708. PMid:31905019.

Guevara, M., Tejera, E., Granda-Albuja, M. G., Iturralde, G., ChisaguanoTonato, M., Granda-Albuja, S., Jaramillo-Vivanco, T., Giampieri, F., Battino, M., \& Alvarez-Suarez, J. M. (2019). Chemical composition and antioxidant activity of the main fruits consumed in the western coastal region of Ecuador as a source of health-promoting compounds. Antioxidants, 8(9), 387. http://dx.doi.org/10.3390/antiox8090387. PMid:31509991.

Irakli, M., Kleisiaris, F., Kadoglidou, K., \& Katsantonis, D. (2018). Optimizing extraction conditions of free and bound phenolic compounds from rice by-products and their antioxidant effects. Foods, 7(6), 93. http://dx.doi.org/10.3390/foods7060093. PMid:29899303.

Khanam, Z., Sam, K. H., Zakaria, N. H. B. M., Ching, C. H., \& Bhat, I. U. H. (2015). Determination of polyphenolic content, HPLC analyses and DNA cleavage activity of Malaysian Averrhoa carambola L. fruit extracts. Journal of King Saud University - Science, 27(4), 331-337. http://dx.doi.org/10.1016/j.jksus.2015.01.004.

Kopjar, M., Orsolic, M., \& Pilizota, V. (2014). Anthocyanins, phenols, and antioxidant activity of sour cherry puree extracts and their stability during storage. International Journal of Food Properties, 17(6), 1393-1405. http://dx.doi.org/10.1080/10942912.2012.714027.

Kurup, S. B., \& Mini, S. (2017). Averrhoa bilimbi fruits attenuate hyperglycemia-mediated oxidative stress in streptozotocin-induced diabetic rats. Yao Wu Shi Pin Fen Xi, 25(2), 360-368. http://dx.doi. org/10.1016/j.jfda.2016.06.007. PMid:28911678.

Lee, C., Kim, S.-Y., Eum, S., Paik, J.-H., Bach, T. T., Darshetkar, A. M., Choudhary, R. K., Hai, D. V., Quang, B. H., Thanh, N. T., \& Choi, S. (2019). Ethnobotanical study on medicinal plants used by local Van Kieu ethnic people of Bac Huong Hoa nature reserve,
Vietnam. Journal of Ethnopharmacology, 231, 283-294. http://dx.doi. org/10.1016/j.jep.2018.11.006. PMid:30412749.

Leong, L. P., \& Shui, G. (2002). An investigation of antioxidant capacity of fruits in Singapore markets. Food Chemistry, 76(1), 69-75. http:// dx.doi.org/10.1016/S0308-8146(01)00251-5.

Li, Z., Shi, W., Cheng, L., Pan, S., \& Wang, C. (2018). Screening of the phenolic profile and their antioxidative activities of methanol extracts of Myrica rubra fruits, leaves and bark. Journal of Food Measurement and Characterization, 12(1), 128-134. http://dx.doi. org/10.1007/s11694-017-9623-1.

Lim, Y. S., \& Lee, S. T. (2013). In vitro antioxidant capacities of star fruit (Averrhoa carambola), an underutilised tropical fruit. Journal of Biology, 1(1), 21-24.

Lim, Y. Y., Lim, T. T., \& Tee, J. J. (2007). Antioxidant properties of several tropical fruits: a comparative study. Food Chemistry, 103(3), 10031008. http://dx.doi.org/10.1016/j.foodchem.2006.08.038.

Lin, D., Xiao, M., Zhao, J., Li, Z., Xing, B., Li, X., Kong, M., Li, L., Zhang, Q., Liu, Y., Chen, H., Qin, W., Wu, H., \& Chen, S. (2016). An overview of plant phenolic compounds and their importance in human nutrition and management of type 2 diabetes. Molecules, 21(10), 1374. http://dx.doi.org/10.3390/molecules21101374. PMid:27754463.

Lovrić, V., Putnik, P., Bursać Kovačević, D., Jukić, M., \& DragovićUzelac, V. (2017). The effect of microwave-assisted extraction on the phenolic compounds and antioxidant capacity of blackthorn flowers. Food Technology and Biotechnology, 55(2), 243-250. http:// dx.doi.org/10.17113/ftb.55.02.17.4687. PMid:28867955.

Luximon-Ramma, A., Bahorun, T., \& Crozier, A. (2003). Antioxidant actions and phenolic and vitamin $C$ contents of common Mauritian exotic fruits. Journal of the Science OfFood and Agriculture, 83(5), 496-502. http://dx.doi.org/10.1002/jsfa.1365.

Mahattanatawee, K., Manthey, J. A., Luzio, G., Talcott, S. T., Goodner, K., \& Baldwin, E. A. (2006). Total antioxidant activity and fiber content of select florida-grown tropical fruits. Journal of Agricultural and Food Chemistry, 54(19), 7355-7363. http://dx.doi.org/10.1021/ jf060566s. PMid:16968105.

Mahmood, T., Anwar, F., Abbas, M., \& Saari, N. (2012). Effect of maturity on phenolics (phenolic acids and flavonoids) profile of strawberry cultivars and mulberry species from Pakistan. International Journal of Molecular Sciences, 13(4), 4591-4607. http://dx.doi.org/10.3390/ ijms13044591. PMid:22605997.

Makanjuola, S. A. (2017). Influence of particle size and extraction solvent on antioxidant properties of extracts of tea, ginger, and tea-ginger blend. Food Science \& Nutrition, 5(6), 1179-1185. http:// dx.doi.org/10.1002/fsn3.509. PMid:29188046.

Manda, H., Vyas, K., Pandya, A., \& Singhal, G. (2012). A complete review on: Averrhoa carambola. World Journal of Pharmacy and Pharmaceutical Sciences, 1(1), 17-33.

Marques, L. G., Silveira, A. M., \& Freire, J. T. (2006). Freeze-drying characteristics of tropical fruits. Drying Technology, 24(4), 457-463. http://dx.doi.org/10.1080/07373930600611919.

Muñoz Jáuregui, A. M., Ramos-Escudero, D. F., Alvarado-Ortiz Ureta, C., \& Castañeda Castañeda, B. (2007). Evaluación de la capacidad antioxidante y vegetales promisorios. Revista de la Sociedad Química del Perú, 73(3), 142-149.

Murillo, E., Britton, G. B., \& Durant, A. A. (2012). Antioxidant activity and polyphenol content in cultivated and wild edible fruits grown in Panama. Journal of Pharmacy \& Bioallied Sciences, 4(4), 313317. http://dx.doi.org/10.4103/0975-7406.103261. PMid:23248565. 
Muthu, N., Lee, S. Y., Phua, K. K., \& Bhore, S. J. (2016). Nutritional, medicinal and toxicological attributes of star-fruits (Averrhoa carambola L.): a review. Bioinformation, 12(12), 420-424. http:// dx.doi.org/10.6026/97320630012420. PMid:28405126.

Nobossé, P., Fombang, E. N., \& Mbofung, C. M. F. (2018). Effects of age and extraction solvent on phytochemical content and antioxidant activity of fresh Moringa oleifera L. leaves. Food Science \& Nutrition, 6(8), 2188-2198. http://dx.doi.org/10.1002/fsn3.783. PMid:30510720.

Otero, D., Antunes, B., Bohmer, B., Jansen, C., Crizel, M., Lorini, A., Krumreich, F., \& Zambiazi, R. C. (2020). Bioactive compounds in fruits from different regions of Brazil. Revista Chilena de Nutrición, 47(1), 31-40. http://dx.doi.org/10.4067/S0717-75182020000100031.

Pang, D., You, L., Li, T., Zhou, L., Sun-Waterhouse, D., \& Liu, R. H. (2016). Phenolic profiles and chemical- or cell-based antioxidant activities of four star fruit (Averrhoa carambola) cultivars. RSC Advances, 6(93), 90646-90653. http://dx.doi.org/10.1039/C6RA15692D.

Pătrăuţanu, O. A., Lazăr, L., Popa, V., \& Volf, I. (2019). Mechanism of spruce bark polyphenols extraction. Cellulose Chemistry and Technology, 53(1-2), 71-78. http://dx.doi.org/10.35812/ CelluloseChemTechnol.2019.53.08.

Payal, G., Pankti, K., Manodeep, C., \& Kamath, J. (2012). Phytochemical and pharmacological profile of Averrhoa Carambola Linn: an overview. International Research Journal of Pharmacy, 3(1), 88-92.

Pothasak, Y., Singhatong, S., Natakankitkul, S., Dechsupa, N., Wanachantararak, P., Dechthummarong, C., \& Leelarungrayub, J. (2020). Active compounds, free radicals scavenging and tumor-necrosis factor (TNF- $\alpha$ ) inhibitory activities of star fruit-sweet type (Averrhoa carambola L.) in vitro. Journal of Associated Medical Sciences, 53(1), 19-28.

Rababah, T. M., Al-u'datt, M., Alhamad, M., Al-Mahasneh, M., Ereifej, K., Andrade, J., Altarifi, B., Almajwal, A., \& Yang, W. (2015). Effects of drying process on total phenolics, antioxidant activity and flavonoid contents of common Mediterranean herbs. International Journal of Agricultural and Biological Engineering, 8(2), 145-151.

Rahman, M. M., Khan, F. E., Das, R., \& Hossain, M. A. (2016). Antioxidant activity and total phenolic content of some indigenous fruits of Bangladesh. International Food Research Journal, 23(6), 2399-2404.

Recuenco, M. C., \& Lacsamana, M. S. (2016). Total phenolic and total flavonoid contents of selected fruits in the Philippines. Philippine Journal of Science, 145(3), 275-281.

Rocchetti, G., Blasi, F., Montesano, D., Ghisoni, S., Marcotullio, M. C., Sabatini, S., Cossignani, L., \& Lucini, L. (2019). Impact of conventional/ non-conventional extraction methods on the untargeted phenolic profile of Moringa oleifera leaves. Food Research International, 115, 319-327. http://dx.doi.org/10.1016/j.foodres.2018.11.046. PMid:30599948.

Ruvini, L., Wmmmk, D., Chathuni, J., Rizliya, V., Swarna, W., \& Cj, B. (2017). Effect of different drying methods on antioxidant activity of star fruits (Averrhoa Carambola L. ). Journal of Nutrition and Diet Supplements, 1(1), 1-6.

Saikia, S., Mahnot, N. K., \& Mahanta, C. L. (2015). Optimisation of phenolic extraction from Averrhoa carambola pomace by response surface methodology and its microencapsulation by spray and freeze drying. Food Chemistry, 171, 144-152. http://dx.doi.org/10.1016/j. foodchem.2014.08.064. PMid:25308654.

Saikia, S., Mahnot, N. K., \& Mahanta, C. L. (2016). A comparative study on the effect of conventional thermal pasteurisation, microwave and ultrasound treatments on the antioxidant activity of five fruit juices. Food Science \& Technology International, 22(4), 288-301. http://dx.doi.org/10.1177/1082013215596466. PMid:26190045.

Shofian, N. M., Hamid, A. A., Osman, A., Saari, N., Anwar, F., Pak Dek, M. S., \& Hairuddin, M. R. (2011). Effect of freeze-drying on the antioxidant compounds and antioxidant activity of selected tropical fruits. International Journal of Molecular Sciences, 12(7), 4678-4692. http://dx.doi.org/10.3390/ijms12074678. PMid:21845104.

Shui, G., \& Leong, L. P. (2004). Analysis of polyphenolic antioxidants in star fruit using liquid chromatography and mass spectrometry. Journal of Chromatography. A, 1022(1-2), 67-75. http://dx.doi. org/10.1016/j.chroma.2003.09.055. PMid:14753772.

Shui, G., \& Leong, L. P. (2006). Residue from star fruit as valuable source for functional food ingredients and antioxidant nutraceuticals. Food Chemistry, 97(2), 277-284. http://dx.doi.org/10.1016/j. foodchem.2005.03.048.

Soto-García, M., \& Rosales-Castro, M. (2016). Efecto del solvente y de la relación masa/solvente, sobre la extracción de compuestos fenólicos y la capacidad antioxidante de extractos de corteza de Pinus durangensis y Quercus sideroxyla. Maderas. Ciencia y Tecnología, 18(4), 701-714. http://dx.doi.org/10.4067/S0718-221X2016005000061.

Su, D., Zhang, R., Hou, F., Zhang, M., Guo, J., Huang, F., Deng, Y., \& Wei, Z. (2014). Comparison of the free and bound phenolic profiles and cellular antioxidant activities of litchi pulp extracts from different solvents. BMC Complementary and Alternative Medicine, 14(1), 9. http://dx.doi.org/10.1186/1472-6882-14-9. PMid:24405977.

Tanase, C., Coșarcă, S., \& Muntean, D.-L. (2019). A critical review of phenolic compounds extracted from the bark of woody vascular plants and their potential biological activity. Molecules, 24(6), 1182. http://dx.doi.org/10.3390/molecules24061182. PMid:30917556.

Teles, A. S. C., Chávez, D. W. H., Gomes, F. D. S., Cabral, L. M. C., \& Tonon, R. V. (2018). Effect of temperature on the degradation of bioactive compounds of Pinot Noir grape pomace during drying. Brazilian Journal of Food Technology, 21, 1-8.

Thomas, R., Jebin, N., Saha, R., \& Sarma, D. K. (2016). Antioxidant and antimicrobial effects of kordoi (Averrhoa carambola) fruit juice and bamboo (Bambusa polymorpha) shoot extract in pork nuggets. Food Chemistry, 190, 41-49. http://dx.doi.org/10.1016/j. foodchem.2015.05.070. PMid:26212939.

Thomas, S., Patil, D., Patil, A., \& Naresh, C. (2008). Pharmacognostic evaluation and physicochemical analysis of Averrhoa carambola L. fruit. Journal of Herbal Medicine and Toxicology, 2(2), 51-54. Retrieved from http://www.verypdf.com/

Valduga, A. T., Gonçalves, I. L., Magri, E., \& Delalibera Finzer, J. R. (2019). Chemistry, pharmacology and new trends in traditional functional and medicinal beverages. Food Research International, 120, 478-503. http://dx.doi.org/10.1016/j.foodres.2018.10.091. PMid:31000264.

Vargas-Madriz, Á. F., Kuri-García, A., Vargas-Madriz, H., ChávezServín, J. L., Ferriz-Martínez, R. A., Hernández-Sandoval, L. G., \& Guzmán-Maldonado, S. H. (2020). Phenolic profile and antioxidant capacity of Pithecellobium dulce (Roxb) Benth: a review. Journal of Food Science and Technology, 57(12), 4316-4336. http://dx.doi. org/10.1007/s13197-020-04453-y. PMid:33087946.

Verma, S., Dhaneshwar, S., Ramana, M. V., \& Rawat, A. K. S. (2018). Gas chromatography-mass spectrometry and high-performance thin-layer chromatography quantifications of some physiologically active secondary metabolites in Averrhoa carambola L. fruits. Journal of Planar Chromatography - Modern TLC, 31(3), 207-212. http:// dx.doi.org/10.1556/1006.2018.31.3.5.

Yan, S. W., Ramasamy, R., Alitheen, N. B. M., \& Rahmat, A. (2013). A comparative assessment of nutritional composition, total phenolic, total flavonoid, antioxidant capacity, and antioxidant vitamins of two types of malaysian underutilized fruits (Averrhoa Bilimbi and Averrhoa Carambola). International Journal of Food Properties, 16(6), 1231-1244. http://dx.doi.org/10.1080/10942912.2011.582975. 
Zainudin, M. A. M., Hamid, A. A., Anwar, F., Osman, A., \& Saari, N. (2014). Variation of bioactive compounds and antioxidant activity of carambola (Averrhoa carambola L.) fruit at different ripening stages. Scientia Horticulturae, 172, 325-331. http://dx.doi.org/10.1016/j. scienta.2014.04.007.

Zainudin, M. A. M., Hamid, A. A., Anwar, F., Shofian, N. M., \& Dek, M. S. P. (2012). Effect of fluorescent light on selected antioxidant compounds and antioxidant activity during storage of fresh-cut carambola (Averrhoa carambola L.). Pakistan Journal of Botany, 44(5), 1681-1688.

Złotek, U., Mikulska, S., Nagajek, M., \& Świeca, M. (2015). The effect of different solvents and number of extraction steps on the polyphenol content and antioxidant capacity of basil leaves (Ocimum basilicum L.) extracts. Saudi Journal of Biological Sciences, 23(5), 628-633. http://dx.doi.org/10.1016/j.sjbs.2015.08.002. PMid:27579013. 